NBER WORKING PAPER SERIES

\title{
INTERNATIONAL DETERMINANTS OF RELIGIOSITY
}

\author{
Robert J. Barro \\ Rachel M. McCleary \\ Working Paper 10147 \\ http://www.nber.org/papers/w10147 \\ NATIONAL BUREAU OF ECONOMIC RESEARCH \\ 1050 Massachusetts Avenue \\ Cambridge, MA 02138 \\ December 2003
}

This research was supported by grants from the National Science Foundation and the John Templeton Foundation. We have benefited from comments by Gary Becker, Francesco Caselli, Mark Chaves, Ed Glaeser, Charles Harper, Jason Hwang, Laurence Iannaccone, Greg Mankiw, James Montgomery, Thomas Osang, Robert Woodberry, and participants in several seminars and classes. The views expressed herein are those of the authors and not necessarily those of the National Bureau of Economic Research.

(C)2003 by Robert J. Barro and Rachel M. McCleary. All rights reserved. Short sections of text, not to exceed two paragraphs, may be quoted without explicit permission provided that full credit, including (C) notice, is given to the source. 
International Determinants of Religiosity

Robert J. Barro and Rachel M. McCleary

NBER Working Paper No. 10147

December 2003

JEL No. O1, Z1

\section{$\underline{\text { ABSTRACT }}$}

Two important theories of religiosity are the secularization hypothesis and the religion-market model. According to the former theory, economic development reduces religious participation and beliefs. According to the latter theory, religiosity depends on the presence of a state religion, regulation of the religion market, suppression of organized religion under Communism, and the degree of religious pluralism. We assess the theories by using survey information for 61 countries over the last 20 years on church attendance and religious beliefs. In accordance with the secularization view, overall economic development_—represented by per capita GDP_— tends to reduce religiosity. Moreover, instrumental estimates suggest that this link reflects causation from economic development to religiosity, rather than the reverse. The presence of an official state religion tends to increase religiosity, probably because of the subsidies that flow to organized religion. However, in accordance with the religion-market model, religiosity falls with government regulation of the religion market, Communist suppression, and a reduction in religious pluralism. Although religiosity declines overall with economic development, the nature of the interaction varies with the dimension of development. For example, religiosity is positively related to education and the presence of children and negatively related to urbanization.

Robert Barro Department of Economics

Harvard University

Cambridge, MA 02138

and NBER

rbarro@harvard.edu

Rachel M. McCleary

Weatherhead Center for International Affairs

Harvard University 
Interactions between religion and political economy involve two directions of causation. On one side, a nation's economic and political developments affect its religiosity. In this view, the dependent or endogenous variables are the extent of individual religious participation and beliefs and the role of organized religion in a country's political, legal, and social structure. On the other side, the nature and extent of religiousness influence economic performance. From this perspective, religious activities and beliefs are independent or exogenous variables.

In a previous study (Barro and McCleary [2003]), we used cross-country data to investigate the effects of religious participation and beliefs on economic growth. In this study, we examine the reverse effects, that is, how religiosity responds to economic development and other variables. Two important theories of religiosity are the secularization hypothesis and the religion-market model. According to the former theory, economic development reduces religious participation and beliefs. According to the latter theory, religiosity depends on government intervention, including the establishment of state religion, regulation of the religion market, and the suppression of organized religion, such as under Communism. Also important in this theory is the degree of religious pluralism, measured by the heterogeneity of religions represented in a country.

We begin with a sketch of the two types of theories. Our discussion focuses on how economic variables, religious doctrines, and government policies influence religious participation and beliefs. Then we discuss empirical measures of religiosity, based on international surveys aggregated to the country level. Finally, we use cross-country regressions to analyze how religiosity reacts to economic and demographic variables; government institutions, including the presence of a state religion, regulation of the religion market, and Communist oppression; and to the composition of religions. Our interpretations of these results 
combine ideas from the secularization hypothesis and the religion-market model. As part of this analysis, we use instrumental variables to isolate the causation from an overall indicator of economic development — per capita GDP — to religion, rather than the reverse.

\section{Determinants of Religiosity}

\section{A. Secularization and Related Hypotheses}

Many theories that seek to explain religiosity rely on the secularization hypothesis. ${ }^{1}$

According to this view, economic development causes individuals to become less religious, as measured by church attendance and certain religious beliefs. The beliefs refer to God, an afterlife, heaven, hell, and so on, and may also refer to tendencies of people to characterize themselves as religious. The secularization hypothesis also predicts that economic development causes organized religion to play a lesser role in political decision-making and in social and legal processes more generally. ${ }^{2}$ One manifestation of this force is a tendency for official state churches to be abandoned as countries develop. As the state bureaucracy matures and rule of law begins to function, a constitution is typically put in place, and formal religion tends to be separated from government. As examples, countries such as Mexico, Turkey, Japan, and South Korea dropped their established state churches many years ago. Ireland is a more recent example of this trend. The secularization hypothesis remains controversial, and an important aspect of the present study is to assess its empirical validity in modern data. ${ }^{3}$

\footnotetext{
${ }^{1}$ The hypothesis can be viewed as a part of modernization theory, whereby economic development leads to an array of changes in social and political institutions. Modernization theory, as discussed in Bell (1973) and Inglehart and Baker (2000), relates to the economic determinism of Karl Marx; see, for example, Marx (1913, pp. 11-12). The secularization hypothesis appears in Weber (1930), but he credits the idea to John Wesley-see Wesley's $18^{\text {th }}$ century essay "On the Use of Money" in Wesley (1951). For more recent discussions, see Wilson (1966), Berger (1967), and Martin (1978).

${ }^{2}$ This idea appears in Weber (1930) and has been extended in Wilson (1966), Berger (1967), and Chaves (1994).

${ }^{3}$ For discussions of evidence contrary to the hypothesis, see, for example, Finke and Stark (1992) and Iannaccone and Stark (1994).
} 
Secularization theories tend to stress particular aspects of economic development, such as increased education or urbanization or life expectancy or decreased fertility. However, the predicted sign of the effect on religiosity tends to vary across these aspects of development. For example, more education has different implications from more urbanization.

With respect to education, one argument for secularization is that more educated people are more scientific and are, therefore, more inclined to reject beliefs that posit super-natural forces. Put another way, if religious beliefs are based primarily on ignorance, more educated persons would tend to be less religious. This viewpoint accords with Hume (1757, pp. 182-83) and Freud (1927), who argued that religion derived from irrational human fears and anxieties. They viewed religion as a mechanism for people to ward off forces that they could not rationally explain. According to this view, increased education should be accompanied by reductions in church attendance and religious beliefs.

A contrary argument is that religious beliefs, like many theoretical hypotheses, require abstract thinking or "faith." If highly educated persons are more capable of the speculative reasoning needed for intellectual inquiry, they may also be more able or willing to make the abstractions needed to support religious beliefs. From this perspective, more educated persons might be more religious. ${ }^{4}$

Sacerdote and Glaeser (2001) provide a different reason for why increased education would spur church attendance. They argue that education increases the returns from networks and other forms of social capital. Hence, they predict that more educated persons would participate more in various group activities, including church services. However, in this approach, church attendance bears no special relation to religious beliefs - this attendance is modeled as just one of many ways to build social capital. This analysis predicts no clear relation

\footnotetext{
${ }^{4}$ We are grateful to Greg Mankiw for this argument.
} 
between education and religious beliefs, except in so far as more frequent church attendance instills greater beliefs.

Models that focus on the role of salvation and the after-life, ${ }^{5}$ such as Azzi and Ehrenberg (1975), predict that people would become more religious as they age and, hence, get closer to death. Similarly, for a given age, increased life expectancy would decrease religiosity. These conclusions follow if salvation depends on cumulated religious effort, including church attendance and prayer, during one's lifetime. In this case, because of discounting of future expenditures, it would be desirable to postpone "outlays" until later in life.

The arguments about age and life expectancy are stronger if salvation corresponds to a stage toward the end of life, as in Hinduism, or if the religious doctrine provides little incentive to avoid wrongdoing when young, as in Catholicism. Weber (1930) observed that the Catholic religion allowed for a continual cycle of sinning and absolution. ${ }^{6}$ Therefore, people have an incentive to accumulate sins early in life and then repent as they get closer to death. Weber argued that this pattern did not apply to Calvinist Protestantism, which dictated daily moral conduct throughout one's life as the only means of finding a sign that one had been chosen. ${ }^{7}$

Muslim doctrine is similar to Catholic doctrine in that redemption is possible, even in Purgatory, by believing in Allah and ascribing to the Five Pillars of Islam. Thus, an older

\footnotetext{
${ }^{5}$ In religions outside of Judaism-Christianity-Islam, the role of an after-life is less clear. For example, Hinduism does not have an after-life or heaven, per se, but does allow for reincarnation and the potential to reach eventually a state of perfection or enlightenment. In terms of incentives, the potential for achieving this enlightenment can play a role analogous to that of an after-life. Buddhism is, in many respects, similar to Hinduism, but without the stress on physical reincarnation. For further discussion, see McCleary (2003).

${ }^{6}$ This cycle is consistent with the old Catholic practice of selling dispensations to sinners. Luther's dissatisfaction with the corruption of this regime was an important force behind the Protestant Reformation. See Ekelund, Hebert, and Tollison (2002) for an economic analysis of the Reformation.

${ }^{7}$ According to Weber (1930, p. 117), "The God of Calvin demanded of his believers not single good works, but a life of good works combined in a unified system. There was no place for the very human Catholic cycle of sin, repentance, atonement, release, followed by renewed sin."
} 
person — even one that has already been condemned — can always rise above past sins. Hence, the Muslim religion also motivates devout behavior especially at advanced ages.

In Buddhism, a person is continually searching for knowledge to acquire enlightenment and, therefore, has no incentive to defer religious investments. Hinduism—out of which Buddhism originated — is less clear-cut, because lay persons are supposed to focus their pursuit of individual salvation in the last stage of their lives. However, earlier stages entail religious obligations that contribute indirectly to a person's ultimate enlightenment.

Economic reasoning predicts that increases in the cost of religious activities would, ceteris paribus, reduce these activities. For example, economic development raises the value of time, as measured by market wage rates. Hence, development implies a rising opportunity cost of participating in time-intensive activities, such as church services and prayer. On this ground, development tends to reduce church attendance and other religious activities. However, this argument assumes that the enhanced productivity that applies generally in the economy (as signaled by rising wage rates) is not accompanied by similar productivity gains for time spent in church or at prayer.

Aging can also affect the cost of churchgoing, especially for the sick and elderly. On this ground, the prediction is that people who are ill or very old would attend church relatively little and, perhaps, engage in relatively more prayer at home. These effects offset the influences mentioned before about a person's response to being relatively close to death. However, despite the relatively low rates of church attendance, the sick and elderly may hold strong religious beliefs, that is, they may invest heavily in personal "spiritual capital."

Children tend to attend church relatively often because their costs of attendance are comparatively low. This effect is reinforced because the productivity of attendance —in the 
sense of the beliefs engendered through "indoctrination"-is likely to be high at young, formative ages. This effect offsets the regular age influence discussed earlier. Moreover, the incentive to bring children to church tends to induce greater church attendance of adults, who are likely to want to participate in the process of inculcating their children and in ensuring that religious values and traditions are transmitted across generations.

Urbanization is another aspect of economic development that has been argued to have a strong negative effect on religiosity. One reason is that church services have to compete in urban areas with many other forms of leisure activities, such as museums, theatres, and political organizations. A possible explanation for this urban/rural pattern is that economies of scale are important for museums and many other social organizations but are less significant for churches. Since a community of believers can meet in a home, even sparsely populated rural towns can sustain a local congregation. Another argument is that rural areas are dominated by agriculture, which is especially prone to the uncertainties of nature. Greater church attendance in rural areas may then reflect a greater demand for religion as a way to cope with these uncertainties.

Wilson (1966) and Berger (1967) continued a theme from Weber (1930) by arguing that economic development leads to the secularization not only of individuals but also of political and social institutions, including the churches themselves. On the political level, organized religions would be predicted to play a smaller role in governance and legislation. Notably, official state churches would become less frequent, and separation between church and state would become more common. Organized religion would be predicted to have a decreasing influence over regulations involving such matters as market transactions, marriage, divorce, birth control, abortion, and euthanasia. Church services would be predicted to become less demanding, for example, by abandoning the use of a "foreign" language, requiring smaller outlays of time by 
participants, reducing elaborate rituals, and requiring less stringent practices by adherents. Part of this process, according to Weber (1930) and Troeltsch (1931), is that religious sects- to be popular and attract adherents — tend to become less other-worldly and stringent.

\section{B. Religious Competition and the Religion-Market Model}

Another argument by secularization theorists is that religiosity is fostered by the existence in a country of a monopoly provider of religion, for example, by the presence of an established state church. If competition existed among churches, much of this competition would take the form of debunking the religious beliefs practiced by others. If the beliefs were based primarily on superstition and ignorance, the argument is that these beliefs could not withstand the competition. Hence, according to this view, the demise of official state churchespredicted to be a part of the secularization process - would tend to foster the decline in individual church attendance and beliefs. Some of this argument appears in Smith (1791, Book $\mathrm{V}$, Article III) and is attributed partly to Hume (1757).

However, Smith also notes that monopoly providers of religious services tend-as monopolies do generally — to become non-innovative and indolent. He particularly observed this behavior in the Catholic Church and the Church of England. Specifically, he argued that the behavior of state religions reflected the lack of strong connection between financial support and the provision of good service to "customers." Under monopoly, state religions tended to lose the aspects of religious devotion that were relevant to people practicing their faith. Moreover, state religions tended to become a religion for elites, and - to the extent that the clergy itself became an elite group — of elites. Consequently, instead of focusing on the religious needs of their congregants, the clergy tended to engage in secular activities, including politics, the arts, and 
intellectual learning. In other words, having reached a level of affluence and a substantial degree of disconnection between income and service quality, the clergy were not motivated to provide a high level of customer satisfaction.

Religions, such as Protestantism, whose clergy depend directly on customer contributions must continually address the needs of congregants to stay in business. Hence, new religious movements or "upstarts," such as the Lutherans and Calvinists during the Reformation in Switzerland and Germany, the Methodists and Quakers in $18^{\text {th }}$ century England, and Evangelical Protestants today in the United States, Latin America, and Asia, are able to enter the religion market by providing better service to members. Similarly, Ekelund, Hebert and Tollison (2002) argue that the medieval Roman Catholic Church lost popularity because of its monopolistic pricing practices and because of its inability to adapt to changing socio-political conditions, especially the decline of feudalism. The discontent with the Catholic Church fostered the popularity of Protestantism among the poor and the royalty. In response to this type of entry, the established state religions sometimes resorted to coercion, repression, and violence to maintain their financial, political, and social arrangements. The Inquisition in Spain in the late 1500s is an extreme example.

Religion, Smith argued, is more vibrant where there is a disassociation between church and state, because the absence of state religion creates a climate for competition among religion providers (Smith [1791, Book V, Article III]). By showing no preference for a particular religion, but rather permitting any religion to be freely practiced, Smith argued that the state would create an open market in which rational discourse among religious groups generated a public display of "good temper and moderation." In an open market, Smith predicted a continual subdividing of sects so that a pluralistic structure would emerge in which no religion dominated. 
He also contended that state support for religious monopoly would promote zealousness and the imposition of ideas on a public that lacks choices. In contrast, where there is an open market for religion, his prediction was that one would find moderation and reason.

Jeremy $(1988,1998)$ extended the Smithian view by arguing that deregulation of the religion market would unleash competitive forces even if the upstarts did not achieve large memberships. The focus of his argument is on the legal recognition of non-conformist Protestant denominations during the 1700s in England (see Worsley [1816], Ashton [1924], and Hagen [1962]). Part of the appeal of these groups was that they offered different visions of the link between salvation and economic activity. Although these groups did not become dominant in religious membership, they did become important in manufacturing.

The Smithian perspective on religious competition has been used by Stark and Bainbridge (1987), Finke and Stark (1992), Iannaccone (1991), and Finke and Iannaccone (1993) to develop a religion-market model of religious participation. Their argument is that greater religious pluralism - measured, for example, by an index of the diversity of religions that exist in a country or region — tends to promote better service and, hence, encourages religious participation. ${ }^{8}$ Moreover, an established state church —as in Scandinavia-is viewed as the typical source of a low degree of religious pluralism and, hence, of low participation in organized religion. However, the connection between pluralism and religious beliefs would be expected to be weaker than that between pluralism and church attendance. For example, Davie (1994) argued for post-World War II Britain that people could curtail participation in formal religion while still maintaining high levels of religious beliefs.

Chaves and Cann (1992) extended the supply-side argument by using empirical measures of the extent of state involvement and interference with church activities. Greater state

\footnotetext{
${ }^{8}$ For a critical survey of this work, see Chaves and Gorski (2001).
} 
regulation of religion - which Chaves and Cann measured by, among other things, whether the government appoints or approves church leaders - was argued to decrease the efficiency of religion providers and, hence, to generate low rates of church attendance. However, state religion also typically involves subsidies, such as payments to church employees and collections of taxes dedicated to church uses. Economic reasoning suggests that these subsidies would encourage formal religious activity. For example, if the government pays for additional church employees, buildings, and religion students, we would expect to see more such employees, buildings, and students. ${ }^{9}$ More personnel and improved facilities may, in turn, attract more church-goers. The point is that, through subsidies, a state religion may have a positive effect on religious participation. Berman (1999) argues, however, from the Israeli experience that state subsidies tend to increase participation but reduce productivity.

The opposite of subsidy is suppression, and some governments have sought to suppress religion, either specific ones or in general. For example, Communist countries, such as the Soviet Union and China, tried hard to eradicate organized religion. A likely reason is that organized religion was regarded as competitive with the Communist quasi-religion. More recently, former Soviet republics in central Asia have sought to curtail Protestant and other “newcomer" religions (see Anderson [2002]). These forms of oppression would be predicted to lower church attendance. From an empirical perspective, it is interesting to examine not only the impact of Communism on church attendance and religious beliefs but also the changes that occurred since the elimination of Communism in many countries in the 1990s.

Future research will be able to exploit the Religion and State (RAS) data set, described in Fox and Sandler (2003), to measure state subsidy and suppression of religion. The RAS

\footnotetext{
${ }^{9}$ Other forms of subsidy, such as the favorable tax treatment of the religion sector in the United States, would have a similar effect.
} 
tabulation describes the relation between religion and state in four categories: separation of religion and state, discrimination against minority religions, restrictions on majority religions, and religious legislation. These data will eventually be available for most countries back to 1960. However, we cannot use these data for our current study, because the tabulation is complete only for a subset of countries and only starting in 1990.

\section{Data on Religiosity}

Our empirical research began with a previously constructed broad cross-country data set. The data include national-accounts variables and an array of other economic, political, and social indicators. The main sources of these data are Heston, Summers, and Aten (2002), World Bank (2002), and Barro and Lee (2001).

We have expanded this data set to include measures of religiosity. The most useful sources of international data on church attendance and religious beliefs seem to be the surveys in the three waves of the World Values Survey or WVS (1981-84, mostly 1981; 1990-93, mostly 1990; and 1995-97, mostly 1995 and 1996), the two reports on religion by the International

Social Survey Programme or ISSP (1990-93, mostly 1991; and 1998-2000, mostly 1998), and the Gallup Millennium Survey (1999). Another wave of the WVS applies to 2000-01 and will soon be available. At present, we are using the survey data only to form country averages of data. This perspective accords with our analysis in this paper of country-wide aspects of religion, notably the state of economic development and the presence of official state churches and regulation of the religion market. In subsequent analysis, we plan to use the individual data, which typically apply to $1000-2000$ respondents in each survey. 
Putting the various sources of religion data together, and considering the availability of data on other variables, we are presently able to carry out statistical analysis for up to 61 countries, which includes up to 24 countries observed around 1981, 38 around 1990, 22 around 1991, 33 around 1995, 28 around 1998, and 43 around $1999 .{ }^{10}$ The maximum number of country-time observations is 188 . The exact sample size depends on the measure of religiosity. The forthcoming fourth wave of the WVS for 2000-01 provides religion data for around 70 countries for which data on other variables are also available. Hence, this new wave will allow a substantial increase in the sample.

Table 1 shows the 61 countries in the sample. The coverage is better for rich countries than for poor ones and for countries that are primarily Christian. ${ }^{11}$ The predominantly Muslim countries are Bangladesh, Malaysia, Pakistan, and Turkey, with Nigeria also having substantial Muslim representation. ${ }^{12}$ Countries that have predominantly eastern religions (including Buddhist), among persons expressing some religious adherence, are China, Hong Kong, Japan, South Korea, Singapore, Taiwan, and Thailand. ${ }^{13}$ Malaysia also has substantial representation in these religions.

\footnotetext{
${ }^{10}$ For the 1981 data, the information from WVS is combined with Gallup data on weekly church attendance and belief in God for Bulgaria, Poland, and Romania and with Gallup data on belief in life-after-death for Brazil, India, Philippines, Singapore, and Thailand. For the 1990 data, the information from WVS is combined with data from Eurodim for Greece in 1987 on church attendance and belief in God. For the 1991 data, for some countries for which church attendance data were unavailable from the 1991 ISSP, we used information from the 1993 or 1994 ISSP (which has information on church attendance but not religious beliefs). These countries are Canada, Israel, Japan, Spain, Sweden, Bulgaria, Czech Republic, and Slovenia. For Israel and Slovenia, the 1991 ISSP has data on religious beliefs but not church attendance. The data for Israel from the 1991 and 1993 ISSP refer to the Jewish population only, whereas the 1998 data refer to the overall Israeli population. Our analysis takes account of these differences in religious composition. The data from WVS and ISSP give separate information for Great Britain and Northern Ireland. In the present analysis, we combined these results into single observations for the United Kingdom, based on the relative populations of Great Britain and Northern Ireland.

${ }^{11}$ Included here are several countries that are predominantly Orthodox-Cyprus, Greece, Bulgaria, Romania, and Russia. Estonia and Latvia also have high Orthodox representations.

${ }^{12}$ The 2001 wave of the WVS will allow a substantial increase in observations on Muslim countries.

${ }^{13}$ Some of these countries, notably South Korea, have experienced large increases in Christian adherence over the last 30 years. The 2001 wave of the WVS will allow a substantial increase in observations on eastern countries.
} 
Some of the survey questions relate to attendance at religious services. We use these responses to generate the fractions of the population that attended church or analogous houses of worship at least weekly and at least monthly. Subsequently, we call this variable church attendance. Some of the surveys (the two ISSP waves) include questions about time spent at prayer. Other queries concern religious beliefs and attitudes; for example, do you believe in heaven, hell, life after death, and God (in various senses) $?^{14}$ Other questions, which might be more robust across religions, are whether the respondent considers himself or herself to be a religious person and whether religion plays an important role in a person's life.

We have used the first edition of the World Christian Encyclopedia (Barrett [1982]) to assemble information on religious adherence, as professed in surveys or censuses in which people are asked to state the religion, if any, to which they adhere. The data apply to 1970 and $1980 .{ }^{15}$ These data allow us to construct measures of religious pluralism, based on Herfindahl indexes of adherence to the main religions. ${ }^{16}$ Table 1 shows the values that apply in 1980 to the countries used in the statistical analysis (as dictated by data availability). Countries with low

\footnotetext{
${ }^{14}$ The meanings of some of these questions are clearer for some religions than others. For example, Hinduism and Buddhism view heaven and hell as intermediate stages between reincarnations, whereas Christianity regards heaven and hell as ends, not means, to salvation. See McCleary (2003) for further discussion.

${ }^{15}$ For some of the eastern European countries, which did not exist or were not covered in Barrett's (1982) first edition, the data come from Barrett, Kurian, and Johnson (2001) and refer to 1970 and 1990. An alternative procedure would be to use the country-wide averages of religion data in the various surveys. We did not proceed this way because the categories of religion differ across the surveys.

${ }^{16}$ The pluralism measure is one minus the Herfindahl index for religions among those professing some religion. For this purpose, we grouped data on religious adherence from Barrett (1982) for 1980 into nine major categories: Catholic, Muslim, Protestant, Hindu, Buddhist, other eastern religions, Jewish, Orthodox, and other religions. The Herfindahl index - the sum of the squares of the fractions belonging to each religion — can be interpreted as the probability that two randomly selected persons in a country, among those professing some religion, belong to the same religion. Hence, one minus the Herfindahl index is the probability that they belong to different religions and can, therefore, be viewed as an indicator of religious pluralism. (Implicitly, the differences between the religious groupings are assumed to be the same for all pairs. Otherwise, one could weight religions in accordance with the extent of differences between them.) The Herfindahl index equals one and, hence, the pluralism indicator equals zero if everyone belongs to the same religion. If there are two religions of equal size, the Herfindahl and pluralism variables each equal one-half. The Herfindahl index equals (almost) zero and, hence, the pluralism indicator equals (almost) one if there are a large number of religions each of which covers a negligible fraction of the population. With nine groupings, the lowest possible value of the Herfindahl index is 0.11 , so that the highest possible value of the pluralism measure is 0.89 .
} 
levels of pluralism include some that are predominantly Catholic (Spain, Italy, Portugal, Belgium, Ireland, and much of Latin America), Protestant Scandinavia, Orthodox Greece, and Muslim Pakistan and Turkey. Places that exhibit high levels of pluralism include the United States, Germany, the Netherlands, Switzerland, Australia, Malaysia, Singapore, Nigeria, and South Africa.

We used Barrett, Kurian, and Johnson's (2001, pp. 834-35) tabulations to measure the presence or absence of a state religion. These classifications are clearer in some cases than others. In some of the straightforward situations, the constitution designates an official state church and restricts or prohibits other forms of religion. However, even without these designations or prohibitions, the government may systematically favor a religion through subsidies and tax collections or through the teaching of religion in public schools. These considerations caused Barrett, et al, to classify some countries as having a "state religion," despite the absence of an official state church in the constitution. Controversial cases in this category include Italy, Portugal, and Spain, which are considered by Barrett, et al, to have a Catholic state religion even in 2000. Table 1 shows the classifications in 1970 for the countries used in the analysis. In subsequent work, it will be possible to use Fox and Sandler's (2003) Religion and State data set, which we already described, to get improved measures of state religion.

We used Barrett's (1982) and Barrett, Kurian and Johnson's (2001) discussion of each country (supplemented in some cases by individual country reports) to obtain a proxy for state regulation of religion. We used the concept suggested by Chaves and Cann (1992) - whether the government appoints or approves church leaders. The Barrett, et al, discussions of this concept typically refer to the late 1970 s. However, the information is often incomplete and not fully 
consistent across countries. The data used in the present analysis are in Table 1. The Religion and State data set will eventually also provide improved measures of this variable.

\section{Cross-Country Findings on the Determinants of Religiosity}

\section{A. Setup of the Analysis}

Table 2 shows the means and standard deviations of the variables used in the analysis.

Table 3 reports the results from panel regressions in which measures of religiosity are related to a set of explanatory variables that includes per capita GDP as the indicator of economic development. ${ }^{17}$ The other explanatory variables are the dummy variables for state religion and state regulation of religion, dummy variables for the presence and subsequent removal of Communist governments, the composition of a country's adhering population among the major religions, and the measure of religious pluralism, which is constructed from the adherence data. ${ }^{18}$

Table 3 contains seven systems, corresponding to different measures of religiosity. The measures are the fraction of the population attending church at least weekly (column 1), fraction attending at least monthly (column 2), fraction who believe in heaven (column 3), fraction who believe in hell (column 4), fraction who believe in an after-life (column 5), fraction who believe in God (column 6), and fraction who consider themselves religious (column 7). ${ }^{19}$ We refer to the

\footnotetext{
${ }^{17}$ The GDP data are from version 6.1 of the Penn World Tables, as described in Heston, Summers, and Aten (2002). These values, available on the Internet, adjust for purchasing power differences across countries.

${ }^{18}$ Inglehart and Baker (2000) use a single cross-section from the World Values Survey to assess the relation of religious and other values to per capita GDP and industrial structure. They also look at effects from different religions and from a history of Communist government.

${ }^{19}$ In the WVS and ISSP surveys, we coded an individual's dummy for belief in heaven or hell, respectively, as one if the respondent answered yes to the question "Do you believe in Heaven?" or "Do you believe in Hell?" These questions are not in the Gallup Millennium Survey. We coded an individual's dummy for belief in an after-life as one in WVS if the respondent answered yes to the question "Do you believe in life after death?" For ISSP, we coded the dummy as one if the respondent answered yes, definitely, or yes, probably, to the question "Do you believe in life after death?" The after-life question was not in the Gallup Millennium Survey. We coded an individual's belief-in-God dummy as one in WVS if the respondent answered yes to the question "Do you believe in God?" For ISSP, we coded the dummy as one if the respondent selected any of the following: "I know God really exists and I have no doubts about it;" "While I have doubts, I feel that I do believe in God;" "I find myself believing
} 
last variable as religiousness. The form of each dependent variable is the transformation $\log [\mathrm{x} /(1-\mathrm{x})]$ of the original series $\mathrm{x}$. This form confines the fitted value of $\mathrm{x}$ to the interval $(0,1) .^{20}$

Each system comprises five or six equations corresponding to the religiosity survey data: the first is for data around 1981 from the World Values Survey (WVS), the second is for data around 1990 from WVS, the third is for data around 1991 from the International Social Survey Programme (ISSP), the fourth is for data around 1995 from WVS, the fifth is for data around 1998 from ISSP, and the last is for 1999 data from Gallup (available only for church attendance and belief in God).

The panel estimation technique allows us to combine countries that are represented in different surveys, as well as to include multiple observations for a single country. We recognize, however, that observations at different points in time or from different survey sources for a single country would not be independent. Therefore, we use the method of seemingly unrelated regression (SUR), which estimates, along with the coefficients, the correlations of the error terms in the equations for the different surveys for a given country. ${ }^{21}$ We also allow for differences in

in God some of the time, but not at others;" and "I don't believe in a personal God, but I do believe in a Higher Power of some kind." (Results were similar if we used a more stringent definition of belief in God from the ISSP surveys.) For the Gallup Millennium Survey, we coded the dummy as one if the respondent answered yes to whether "there is a personal God" or whether "there is some sort of spirit or life force." We coded an individual's religiousness dummy as one in WVS if the respondent answered yes to the question "Independently of whether you go to church or not, would you say you are a religious person?" For ISSP, we coded the dummy as one if the respondent selected any of the following: "Would you describe yourself as 1. extremely religious, 2. very religious, or 3. somewhat religious?" The religiousness variable was not in the Gallup Millennium Survey.

${ }^{20} \mathrm{In}$ this form, the marginal effect of an independent variable on $\mathrm{x}$ equals the coefficient of the variable multiplied by the quantity $\mathrm{x} \cdot(1-\mathrm{x})$. Hence, the marginal effect of an explanatory variable on $\mathrm{x}$ diminishes in magnitude as $\mathrm{x}$ approaches zero or one. For a broad range of $\mathrm{x}$ - say between 0.2 and 0.8 - the functional form is roughly linear.

${ }^{21}$ For a discussion of the SUR technique, see Wooldridge (2002, ch. 7). 
average survey results across the sources by including a different intercept term for each

source-WVS, ISSP, and Gallup. ${ }^{22}$

For the composition of the population by religion, we use an eight-way breakdown for 1980 among Catholic, eastern religions (including Buddhist), Hindu, Jewish, Muslim, Orthodox, Protestant, and other religions. ${ }^{23}$ In each case, the variable refers to the fraction adhering to the specified religion among persons who expressed adherence to some religion. ${ }^{24}$ The Catholic fraction is the left-out category. Hence, each coefficient should be interpreted as the effect from the indicated religion relative to that for Catholic.

\section{B. Relations with Economic Development}

The results in Table 3 show significantly negative relationships between economic development, as gauged by per capita GDP, and the measures of religiosity, except for religiousness. For example, for monthly church attendance, the estimated coefficient on the log of per capita GDP is $-0.52($ s.e. $=0.10)$. This coefficient means that, when evaluated at the sample mean of monthly attendance, a one-standard-deviation increase in the log of per capita GDP (by 0.77 , as shown in Table 2) reduces the attendance rate by 9 percentage points (from 0.37 to 0.28 ). For belief in heaven, the estimated coefficient is -0.80 (s.e. $=0.13$ ). This

\footnotetext{
${ }^{22}$ Formally, we included a constant term and two dummy variables, one for the ISSP source and one for the Gallup source. The Gallup dummy was included only in the systems for church attendance and belief in God, for which the Gallup data were available.

${ }^{23}$ Buddhist and other eastern religions were combined because of a lack of sufficient data from Asian countries to distinguish these two categories. For the pluralism indicator, we used a nine-way breakdown that distinguished Buddhist from other eastern religions. Our present data do not allow us to differentiate among theological subgroups, for example, types of Muslims and Protestants.

${ }^{24}$ The composition of religious adherence across persons who exhibit some adherence may be exogenous with respect to church attendance and religious beliefs. However, it is unreasonable to regard the breakdown between some and no adherence (appearing in the data as non-religious or atheist) as exogenous with respect to attending church or holding religious beliefs. Therefore, it would be inappropriate to include among the explanatory variables a measure of the fraction of the population that expressed no religious adherence.
} 
coefficient means that a one-standard-deviation increase in the log of per capita GDP reduces the belief rate by 15 percentage points (from the mean of 0.56 to 0.41 ).

The findings for the effects of per capita GDP accord with the secularization view. Moreover, we argue later that we can interpret these relations as effects of economic development on religiosity, rather than the reverse. However, we also find that, when we go beyond per capita GDP to bring in additional dimensions of economic development, the relations with religiosity depend a great deal on the particular dimension. For example, as conjectured before, the effects from education are very different from those of urbanization.

\section{Trends in Religiosity}

We can think of trends in religiosity as stemming partly from trends in the explanatory variables in Table 3-for example, long-term increases in per capita GDP — and partly from trends that apply for given values of the explanatory variables. We consider here the second channel, that is, we examine whether there are secular trends in religiosity for given values of the explanatory variables.

For the systems in Table 3, the same constant applies for each survey year, except that dummy variables were included to allow for systematic differences in the three sources: WVS, ISSP, and Gallup. Within the WVS and ISSP data, the same constant terms apply to the surveys from different dates_-WVS for 1981, 1990, and 1995, and ISSP for 1991 and 1998. Therefore, we can test for trends by allowing these constant terms to vary over these dates. This test considers whether, for the WVS surveys, there are systematic differences, for given explanatory variables, in the religiosity data for 1981, 1990, and 1995. Similarly, the test looks for systematic differences in the ISSP data for religiosity in 1991 and 1998. 
The conclusion is that, at the $5 \%$ critical level, the only statistically significant trend is for increasing belief in hell. At the $10 \%$ critical level, there is also evidence for increasing belief in heaven. For both hell and heaven, the main evidence for the rising trends comes from comparisons of the 1995 WVS wave with the two earlier WVS waves. For church attendance, the comparison between the 1991 and 1998 ISSP waves shows some decrease over time. However, the overall trends in church attendance are not statistically significant. Thus, if we think of secularization as a downward trend in religiosity that applies for given economic and other variables, there is no evidence for secularization in this sense.

\section{State Religion, State Regulation, and Communism}

Table 3 shows that the estimated coefficients on the state-religion dummy variable are significantly positive for church attendance and also for beliefs in heaven and hell. For example, for monthly church attendance, the estimated coefficient of $0.75($ s.e. $=0.16)$ in column 2 implies, if viewed causally, that the imposition of a state religion would raise the monthly attendance rate by 18 percentage points (from the mean of 0.37 to 0.55 ). This pattern conflicts with the one predicted in the religion-market model of Stark and Bainbridge (1987), Iannaccone (1991), Finke and Stark (1992), and Finke and Iannaccone (1993). In that view, state religion promotes monopoly and, therefore, poor service and low rates of church attendance. However, since state religion typically goes along with state subsidy, we do not find it surprising that the overall relation between state religion and church attendance would be positive, and we do find this pattern in our data.

These results apply when we use the status of state religion as of 1970. Our sample does not contain enough changes in state religion after 1970 to assess the dynamic responses of 
church attendance and religious beliefs. The main example of a shift since 1970 is Ireland's abandoning Catholicism as its state religion in 1972, although Barrett, Kurian, and Johnson (2001) continue to classify Ireland as officially religious but not officially Catholic. Legislative changes also occurred after 1970 in Italy, Portugal, and Spain, but Barrett, et al, continue to label these countries as maintaining Catholic state religions even in 2000. More recently, Sweden dropped the Lutheran church as its state religion, and Bulgaria established the Eastern Orthodox Church. If we compare 1970 with 1900 , we find many examples of countries abandoning state religions. Using Barrett, et al's (2001) data, examples for countries in our sample are Brazil, Chile, China, Japan, South Korea, Turkey, Latvia, Lithuania, Romania, and Russia. Some countries that were not independent in 1900 (Bangladesh, Israel, and Pakistan in our sample) introduced state religions when they became independent. ${ }^{25}$

In the 1990s, some countries that were formerly parts of the USSR and Yugoslavia introduced features of state religions. However, these countries lack sufficient historical data to be included in our sample. Based on information from Barrett, et al (2001) and U.S. State Department reports, countries that introduced aspects of a Muslim state religion are Azerbaijan, Kyrgyzstan, Tajikistan, Turkmenistan, and Uzbekistan. Those implementing aspects of an Orthodox state religion are Armenia, Belarus, Georgia, Macedonia, Moldavia, and Ukraine. Croatia introduced some features of a Catholic state religion. In a later study, we plan to assess the rise of state religions in the former Communist countries.

The results for state religion in Table 3 apply when we hold constant a measure of religious pluralism (discussed below). One part of the argument in the religion-market model is

\footnotetext{
${ }^{25}$ We also have information from Barrett, Kurian, and Johnson (2001) on governments that are officially religious, although not maintaining a single religion. Examples in 1970 for countries in our sample are South Africa, Brazil, Philippines, Belgium, Cyprus, Germany, Switzerland, and Australia. If we enter an additional dummy variable into the systems of Table 3 to capture this officially religious category, the estimated coefficients on this new variable are close to zero.
} 
that an established state religion will help to maintain monopoly in the religion market and, thereby, a low degree of religious pluralism. Hence, the pluralism variable could be getting credit for influences on religiosity that stem ultimately from the presence of an established religion. If we delete the pluralism index from the system for monthly church attendance, the estimated coefficient on the state religion dummy becomes 0.31 (s.e. $=0.15$ ), which is smaller than before but still significantly positive. Our analysis also includes the dummy variable for the presence of state regulation of religion. Since this regulatory system often accompanies a state religion (see Table 1), the regulatory variable could be getting credit for effects that stem ultimately from state religion. If we delete the regulatory variable, as well as the pluralism index, from the system for monthly church attendance, the estimated coefficient on the state religion dummy falls further to 0.08 (s.e. $=0.14$ ), which is statistically insignificantly different from zero. The same pattern of results applies for the systems for weekly church attendance and for beliefs in heaven and hell. Thus, our finding of a positive relation between state religion and religiosity depends on our holding constant the measures of religious pluralism and state regulation of religion.

In the literature, the Scandinavian countries are often cited as places in which state churches co-exist with low rates of church attendance. That pattern does characterize the data in our study. However, the low rates of attendance in these countries are explained reasonably well by the model, despite the positive coefficient on the state-religion dummy. For example, Table 4 shows that, in 1990, the actual and fitted values of monthly church attendance are, respectively, 0.11 and 0.16 for Denmark, 0.11 and 0.10 for Finland, 0.13 and 0.10 for Norway, and 0.10 and 0.11 for Sweden. The reason for the good fit for the Scandinavian countries is that the other 
variables contained in the system, especially per capita GDP and the composition of religions (discussed in the next section), predict low levels of religiosity.

The results in Table 3 indicate that government regulation of religion tends to depress church attendance, religious beliefs, and religiousness. The estimated coefficients are all significantly negative except for the one for belief in an after-life (column 5). Hence, in contrast to our results on state religion, our findings on regulation support the arguments from the religion-market model. Better measurement of the indicator for regulation of the religion market may sharpen these results.

For monthly church attendance, the estimated coefficient of $-0.57($ s.e. $=0.12)$ on the state regulation dummy variable in column 2 of Table 3 means that the introduction of a government regulatory system for religion would lower monthly church attendance by 12 percentage points (from the mean of 0.37 to 0.25 ). As already noted, state religion and government regulation of religion often come as a package — see Table 1. If a state religion is imposed along with regulation, the estimated net effect on monthly church attendance is positive but by only about 4 percentage points.

The presence of a Communist regime has a substantial negative relation with church attendance and religious beliefs. For example, for monthly church attendance, the estimated coefficient of $-0.72($ s.e. $=0.21)$ in column 2 of Table 3 implies that the imposition of Communism would lower the attendance rate by 15 percentage points (from the mean of 0.37 to 0.22$)$.

By comparing the three later surveys-WVS around 1995, ISSP around 1998, and Gallup in 1999 - with the three earlier ones, we can estimate how the downfall of the Communist systems in Eastern Europe affected religiosity. The results are that church attendance and 
religious beliefs tended to recover in the former Communist countries during the $1990 \mathrm{~s} .{ }^{26}$ For example, for monthly church attendance in column 2 of Table 3, the estimated net remaining effect in 1999 from the presence of Communism before 1990 is given by the coefficient on the Communism dummy, -0.72, plus the coefficient for ex-Communism (in 1999), 0.40. Hence, the net remaining effect for 1999 is a coefficient of -0.32 . That coefficient implies a net reduction of monthly attendance in 1999 by only 7 percentage points (from the mean of 0.37 to 0.30 ).

\section{E. Religious Pluralism and the Composition of Religions}

Table 3 shows that the religious pluralism indicator (shown in Table 1) has significantly positive coefficients in the systems for church attendance. This pattern accords with the religionmarket model's argument that greater pluralism would encourage competition among religion providers and lead, thereby, to better service and higher rates of attendance. The estimated coefficient in column 2 of 1.60 (s.e. $=0.34$ ) means that an increase in pluralism by 0.23 (its sample standard deviation) raises monthly church attendance by 9 percentage points (from the mean of 0.37 to 0.46 ). Religious pluralism also has positive relationships with beliefs in heaven and hell and religiousness, but these results are not statistically significant at the $5 \%$ level.

With respect to the composition of religions, recall that each coefficient gives the effect relative to that for Catholic (the omitted category). Recall also that the variables are the fractions

\footnotetext{
${ }^{26}$ Poland is an exception, as it exhibits a small decline in church attendance during the 1990s. However, Poland is even more of an outlier with respect to its high rates of church attendance before the 1990s. The model explains little of the high rate of church attendance in 1990 - see Table 4. Some observers explain the high religiosity during the Communist period by observing that the Catholic church occupied a chief position of political opposition to the government and was popular and important for these reasons. The decline in religious participation in the 1990s could then reflect the elimination of this political role for the church, once the Communist regime collapsed. Although these arguments seem reasonable, they have the shortcoming of explaining the vibrancy of religion in Poland up to 1990 by observing that it was vibrant. The question is, why did religion occupy a different place in Poland than, say, in Hungary or Czechoslovakia, which were also historically predominantly Catholic?
} 
of the population adhering to the indicated religion among persons who express adherence to some religion.

Most of the religions are lower than Catholic in their rates of church attendance. ${ }^{27}$ The main exception is Muslim, which has a significantly positive coefficient for weekly attendance and a positive, but statistically insignificant, coefficient for monthly attendance. For the religious beliefs, most of the religions are again lower than Catholic. However, the Muslim coefficient is positive, as is the one for other religions. Particularly noteworthy is the large positive coefficient for the Muslim religion in the system for belief in heaven and, even more so, for belief in hell.

\section{F. Actual and Fitted Values}

The estimates shown in Table 3 do not, of course, explain all of the cross-country variations in religiosity. To get a sense of what is explained and unexplained, Table 4 shows the actual and fitted values of monthly church attendance and belief in heaven for countries included in the 1990 WVS (37 observations for attendance and 34 for belief). As an example, the United States has often been cited as a country that is surprisingly religious, given its level of per capita GDP and other variables. The table shows that the residuals are indeed positive - the actual attendance of 0.58 compares with the fitted value of 0.36 , and the actual belief in heaven of 0.87 contrasts with the fitted value of 0.57 . However, the United States is not unique as a country with substantial residuals. The largest errors are for Poland, which has much higher levels of religiosity than those predicted by the model.

\footnotetext{
${ }^{27}$ These results can reflect differences across religions in the role of attending church or analogous houses of worship. For example, religions vary by the weight that they attach to organized services versus personal prayer.
} 
Despite the presence of substantial residuals, the model does explain a good deal of the cross-country variation in religiosity. The R-squared values shown in Table 3 indicate the overall fits. The model's explanatory power, including that for the United States, improves when we add additional explanatory variables to describe more detailed aspects of economic development. However, as we discuss later, that extension also makes causal inferences more difficult.

\section{G. Causality and Instrumental Estimates}

A major issue in the interpretation of the estimates in Table 3 is whether they reflect causation from the independent variables to religiosity, rather than the reverse. We think that the main concern arises for per capita GDP — do the coefficients reflect the effect of economic development on religiosity or, in reverse, the effect of religiosity on development?

In our previous study (Barro and McCleary [2003]), we estimated effects of religiositychurch attendance and religious beliefs—on economic growth. To isolate causation from religiosity to growth, we used instrumental variables suggested by the types of results reported in Table $3{ }^{28}$ Specifically, our instruments were the dummy variables for state religion and state regulation of regulation, the composition of adherence across the religions, and the religious pluralism index (which was constructed from the adherence shares). The results indicated that growth responded positively to higher religious beliefs, notably beliefs in hell, heaven, and an after-life, but negatively to higher church attendance for given beliefs. Growth was not much related to the overall level of religiosity — that is, if beliefs and attendance moved together in their usual manner, the net impact on growth was small. Hence, countries that were more or less religious overall tended to grow neither faster nor slower than average.

\footnotetext{
${ }^{28}$ For a discussion of instrumental variables, see Wooldridge (2003, chap. 15).
} 
In Table 3, the dependent variables are levels of religiosity. The main sample variations in these variables — church attendance, beliefs, and religiousness — reflect the overall extent of religiosity in a country. Therefore, our previous results suggest that these religiosity measures would not have much influence on economic growth. Hence, we do not anticipate much reverse causation from levels of religiosity to levels of per capita GDP.

To test this conjecture, we re-estimated systems of the form shown in Table 3 by using instrumental variables for the log of per capita GDP. We constructed the instruments in two ways. The first approach uses an earlier value of the log of per capita GDP—for 1970 — as an instrument. ${ }^{29}$ This procedure isolates the timing from prior levels of economic development to subsequent levels of religiosity. However, this technique may not adequately establish causation because many country-specific variables, including unobserved dimensions of economic development and religiosity, tend to persist strongly over time.

Our second approach uses exogenous geographical features of countries as instruments. The two variables used are the distance from the equator and a dummy variable for land-locked status. The distance variable (measured as the absolute value of degrees latitude) affects climate and, therefore, aspects of agricultural productivity and disease. Land-locked status influences the convenience of transport and, hence, the potential for international trade. These two variables have considerable explanatory power for the log of per capita GDP. As an example, we estimated a SUR system for 151 countries for observations on the log of per capita GDP at ten-year intervals from 1960 to 2000. The system also includes the dummy for Communism and has separate intercepts for each time period. The R-squared values in the five equations are around 0.5 , and the estimated coefficients are $4.14($ s.e. $=0.27)$ on the absolute value of degrees

\footnotetext{
${ }^{29}$ For some Eastern European countries, the earliest available data on GDP are for 1995. The results in Table 4 include these observations in the instrument for the log of per capita GDP. However, the conclusions are similar if we drop these countries from the sample.
} 
latitude, ${ }^{30}-0.36$ (s.e. $\left.=0.10\right)$ on the dummy variable for land-locked status, and -0.67 (s.e. $=$ 0.11 ) on the dummy variable for Communism.

Table 5 shows the estimates of the coefficients of log per capita GDP when the systems for religiosity in Table 3 are re-estimated using our instrumental variables. The coefficients of the other explanatory variables are not shown (and the results do not differ much from those in Table 3). The coefficients in Table 5 should be compared with those for the log of per capita GDP for each corresponding system in Table 3. These earlier results did not use instrumental variables. The important finding is that both sets of instrumental estimates in Table 5 are broadly similar to those in Table 3 . The main difference is a tendency for the instrumental estimates to be higher in magnitude. That is, when we instrument, we find a somewhat greater tendency for increases in per capita GDP to reduce religiosity. ${ }^{31}$ In any event, our allowance for reverse causation from religiosity to economic development leaves intact the conclusion that economic development decreases religiosity.

Although our main concern with reverse causation is with the link between religiosity and per capita GDP, it is possible that endogeneity issues could also arise for other explanatory variables in Table 3. One concern is that greater religiousness might help to explain why a country has a state religion. An opposing argument is that state religions were typically implemented many years in the past, for example, more than 400 years ago in Scandinavia. Hence, the presence of a state religion reflects mainly the long-term history and is largely exogenous with respect to current religiosity. However, it could be argued that less religious

\footnotetext{
${ }^{30}$ Being too close to the equator is clearly bad for an economy. However, being too far away is also bad because eventually temperatures get too cold. To capture this last effect, we entered the square of degrees latitude into the regressions. The coefficient of this variable differed insignificantly from zero because our sample does not include places, such as Greenland and Antarctica, that are excessively far from the equator.

${ }^{31} \mathrm{We}$ would expect this pattern if religiosity had a positive, but not very large, effect on per capita GDP. In that case, the estimates of the GDP coefficients in Table 3 would tend to be biased upward, that is, they would underestimate the magnitude of the negative effect of per capita GDP on religiosity.
} 
nations are more likely to abandon their state religions. To proceed further, we would need a political theory of the propensity to implement and maintain state religion. Although the development of this theory would be interesting, the main empirical problem is likely to be the isolation of exogenous variables that serve as satisfactory instruments for state religion or state regulation of religion.

Another possibility for reverse causation is that differences in religiosity would influence the composition of religious adherence. This process could involve religious conversion and patterns of fertility and immigration that differ across religions. Again, the principal challenge would be to isolate exogenous variables that serve satisfactorily as instruments - in this case, for the composition of religious adherence. We can also note that the religious pluralism index is constructed from the data on religious adherence shares. Hence, the pluralism variable does not raise any new concerns about endogeneity_-if the adherence shares are properly viewed as exogenous with respect to religiosity, then the pluralism index would also be exogenous.

\section{H. Dimensions of Economic Development}

Our results for per capita GDP indicate that the overall effect of economic development is to reduce religiosity. However, as mentioned before, economic development has various dimensions, including increases in education, urbanization, and life expectancy, and reductions in fertility. The patterns in life expectancy and fertility imply that richer countries have an age structure that is tilted more toward the old and away from the young. When we measure economic development solely by per capita GDP, we implicitly combine all of these aspects of development into a single variable. However, the theoretical reasoning in our first section 
suggests that the different aspects of economic development would relate differently to religiosity.

The present panel data set includes enough observations to distinguish the effects from the various dimensions of development. Therefore, we now extend the analysis from Table 3 to include five additional economic-demographic variables: educational attainment, the urbanization rate, life expectancy, and the fractions of the population aged over 65 and under 15 . The education data are from Barro and Lee (2001) and the other data are from World Bank (2002). Life expectancy at age one is entered as a reciprocal and, therefore, measures the average mortality rate per year.

Table 6 shows the estimated coefficients for the new economic-demographic variables, along with the coefficients for the log of per capita GDP. (The other explanatory variables in Table 3 are included, but their coefficients are not shown.) These estimates do not use instrumental variables, because we lack instruments that can distinguish satisfactorily among the various dimensions of economic development. Hence, we have to be cautious about causal inferences - the coefficients in Table 6 represent partial correlations with the religiosity measures.

The results in Table 6 reveal very different patterns for the individual dimensions of economic development. One result is a significantly positive coefficient for education in all of the religiosity systems. For example, the estimated coefficient of $0.192($ s.e. $=0.036)$ in column 2 implies, if interpreted causally, that an increase in average schooling by 2.1 years (the sample standard deviation in Table 2) would raise monthly church attendance by 10 percentage points (from the mean of 0.37 to 0.47 ). The positive partial association between education and church attendance accords with Sacerdote and Glaeser's (2001) analysis, which focused on the 
incentives of educated people to attend group activities, including church services. However, in contrast with their findings, the results in Table 6 also reveal positive partial associations between education and religious beliefs. One clear inference is that the overall negative effect of economic development on religiosity (found in Tables 3 and 5) does not work through education. That is, we cannot conclude that richer societies are less religious because people are better educated.

Another clear pattern in Table 6 is the significantly negative partial relation between the measures of religiosity and the urbanization rate. For example, the estimated coefficient of -1.49 $($ s.e. $=0.34)$ for monthly church attendance in column 2 means, if viewed causally, that an increase in the urbanization rate by 0.16 (its sample standard deviation) would lower monthly attendance by 5 percentage points. Thus, as predicted from theoretical arguments, one reason that richer societies are less religious is probably that the population is more urban.

Table 6 shows that a greater presence of children (higher population share under age 15) goes along with higher religiosity. For example, for monthly church attendance in column 2, the coefficient of $5.5($ s.e. $=2.0)$ means, if viewed causally, that a decrease in the under-15 population share by 0.077 (its sample standard deviation) would lower attendance by 9 percentage points (from the mean of 0.37 to 0.28 ). Hence, as expected from theoretical reasoning, the lesser presence of children in rich societies likely accounts for part of the lower religiosity.

The results for life expectancy and the over-65 age share are more difficult to interpret. For monthly church attendance, in column 2 of Table 6 , the coefficients for mortality (the reciprocal of life expectancy) and the over-65 age share are individually and jointly insignificantly different from zero. The p-value for joint significance of the two coefficients is 
0.18. Thus, we do not find any clear relation of church attendance to life expectancy and the oldage share of the population.

For religious beliefs, the coefficients on mortality and the over-65 age share tend to be negative. For example, for belief in heaven in column 3 of Table 6 , the coefficient of -3.5 $($ s.e. $=2.0)$ means that a decrease in mortality by 0.11 (its sample standard deviation) would raise belief by 9 percentage points (from the mean of 0.56 to 0.65 ). The coefficient of $-9.8($ s.e. $=4.8$ ) implies that an increase in the over- 65 age share by 0.042 (its sample standard deviation) would reduce belief by 10 percentage points (from 0.56 to 0.46 ). These two coefficients are jointly statistically significant $(\mathrm{p}$-value $=0.011)$. However, in thinking about the typical pattern of economic development, we would combine the effect from a decrease in mortality (say by one standard deviation) with an increase in the over-65 age share (again by one standard deviation). Therefore, the results suggest that falling mortality and rising old-age share offset each other and have little overall relation with religious belief. In this sense, the conclusion for religious beliefs is similar to that for church attendance.

The estimates in Table 6 indicate that, once the other economic and demographic variables are held constant, the relations between the religiosity measures and per capita GDP are statistically insignificantly different from zero. Thus, it is likely that the effects of economic development on religiosity do not involve higher income, per se. Rather, the main effects work through changes in education, urbanization, the presence of children, and so on.

The addition of the five explanatory variables in Table 6 does significantly improve the fits of the relationships - the R-squared values shown can be compared with the corresponding values in Table 3. As an example, for the United States in the 1990 WVS, monthly church attendance is 0.58 and the fitted value from Table 6 , column 2 , is 0.49 , compared to the fitted 
value from Table 3 , column 2 of 0.36 . Similarly, for belief in heaven, the actual value is 0.87 and the fitted value from Table 6 , column 2 , is 0.77 , compared to the fitted value from Table 3 , column 2 of 0.57 . Thus, when the detailed dimensions of economic development are considered, the United States is no longer so much of an outlier with respect to its religiosity.

\section{Superstition}

As discussed before, one dimension of the secularization hypothesis - which the data failed to confirm - is that increased education would generate lower levels of church attendance and religious beliefs. The theoretical rationale for this linkage was that religion amounted to superstition and ignorance and, hence, that religious activities would decline as people became better educated.

Another way to assess this hypothesis is to look at other beliefs that seem clearly to reflect superstition and ignorance. The ISSP surveys offer three good candidates: belief in fortune tellers ("some fortune tellers really can foresee the future"), belief in horoscopes ("a person's star sign at birth, or horoscope, can affect the course of their future"), and belief in good-luck charms ("good luck charms sometimes do bring good luck"). The predictive content from these forecasting "tools" should be scientifically testable. Although we have not done the analysis, we take it as plausible that none actually has predictive content.

Data on the three superstition variables are available from the ISSP only for 17 Christian countries, which are listed in Table 7. The table shows the fraction of persons holding each of

the beliefs. We were surprised by the high levels - they range from 19\% of the Irish population believing in horoscopes to $80 \%$ of the Latvian population believing in fortune tellers. Table 8 
shows that there is a strong positive correlation among the three superstitious beliefs. Therefore, we focus on the simple average of the three, as shown in the first column of Table 7. These values range from $25 \%$ in Ireland to $73 \%$ in Latvia.

Table 9 shows, for the 17 countries included in Table 7, the correlations among the religiosity variables considered before. These correlations are strongly positive whether we look at church attendance, religious beliefs, or religiousness. However, the most interesting finding, shown in the first column of Table 9, is that the correlation between the average superstition indicator and each of the religiosity variables is negative. These values range from -0.37 for belief in hell to -0.63 for belief in heaven.

One conclusion is that religious beliefs and superstitious beliefs are very different. A possible reason is that religious beliefs are compatible with increased education and knowledge, whereas the superstitious beliefs are not. ${ }^{32}$ However, another possibility is that the superstitions tend to substitute for religious beliefs and activities in societies where the standard religious practices are suppressed or are unavailable for other reasons. Notably, folk religions anchored in superstition and lacking in the infrastructure of organized religion are likely responses to religious suppression by the central authority. These ideas accord with the observation that the superstition variables, shown in Table 7, are the highest in the formerly Communist countries of Eastern Europe.

Another point is that organized religions, notably the Catholic Church, try to suppress superstitions, including the labeling of some of these practices as sins. Possibly, as in the attempts of Communist governments to eradicate "respectable" religions, the idea is to suppress

\footnotetext{
${ }^{32}$ We do not have sufficient data on the superstition variables to carry out the sort of cross-country statistical analysis done in Tables 3 and 6 .
} 
competition. ${ }^{33}$ The success of this anti-superstition campaign may explain why the superstition variables are particularly low in the most devout Catholic countries included in Table 7, Ireland and the Philippines. This pattern also shows up in a comparison of mostly Protestant Great Britain with mostly Catholic Northern Ireland. The average of the three superstition indicators for Great Britain is 0.32, whereas that for Northern Ireland is 0.25.

\section{Concluding Observations}

Our empirical work used a cross-country panel that includes country level information on religiosity_church attendance, religious beliefs, and religiousness (measured by whether people consider themselves to be religious). These data derive from individual information collected in six international surveys between 1981 and 1999.

We found that the various measures of religiosity tended to decline as an indicator of economic development_ - per capita GDP_increased. Moreover, results from instrumental estimation suggest that this linkage represents causation from economic development to religiosity, rather than the reverse.

We found that the presence of a state religion tended to raise church attendance, religiousness, and some measures of religious belief. We think that these effects arise because of the subsidies that typically flow to the established religions. However, religiosity tended to decline in response to government regulation of the religion market and with the presence of a Communist government. The elimination of the Communist regimes in Eastern Europe led to a recovery of religiosity in most of these countries during the 1990s.

\footnotetext{
${ }^{33}$ The Catholic Church may also have competed by incorporating magical practices into its own ceremonies, notably the Eucharist in which a wafer and wine are ontologically identified as the body and blood of Christ. Luther and subsequent forms of Protestantism denounced these practices as untenable.
} 
Greater religious pluralism, measured by the diversity of adherence among the major religions, tended to raise church attendance. However, pluralism was not significantly related to religious beliefs or religiousness. Across the religions, attendance and beliefs tended to be highest for Muslim, then Catholic, then the other faiths: eastern religions (including Buddhist), Hindu, Jewish, Orthodox, and Protestant.

We also examined the relation of religiosity to detailed dimensions of development: education, urbanization, life expectancy, and the shares of the population that were over 65 and under 15 . We found that the measures of religiosity were positively related to education, negatively related to urbanization, and, in most cases, positively related to the under-15 age share. Religiosity had little overall relation with life expectancy and the over-65 age share. Moreover, once we held fixed these specific aspects of economic development, we found that religiosity was virtually unrelated to per capita GDP.

Future research could usefully extend our findings in a number of directions. One extension would be to use Fox and Sandler's (2003) data—once they become available—to sort out the effects on organized religion from various governmental regulations, subsidies, and prohibitions. Other work would seek to explain the implementation and demise of state religions, with particular emphasis on the changes in the former Communist countries in Europe and Asia. It would also be valuable to assess the relationships between religiosity and political and social indicators, including measures of electoral rights and civil liberties. 


\section{References}

Anderson, J. (2002). “Social, Political, and Institutional Constraints on Religious Pluralism in Central Asia," Journal of Contemporary Religion, 17, 2, 181-196.

Ashton, T.S. (1924). Iron and Steel in the Industrial Revolution, Manchester England, Manchester University Press.

Azzi, C. and R. Ehrenberg (1975). "Household Allocation of Time and Church Attendance," Journal of Political Economy, February, 27-56.

Barrett, D.B. (1982). World Christian Encyclopedia, $1^{\text {st }}$ ed., Oxford, Oxford University Press.

Barrett, D.B., G.T. Kurian, and T.M. Johnson (2001). World Christian Encyclopedia, $2^{\text {nd }}$ ed., Oxford, Oxford University Press.

Barro, R.J. and J.W. Lee (2001). "International Data on Educational Attainment: Updates and Implications," Oxford Economic Papers, 541-563.

Barro, R.J. and R.M. McCleary (2003). "Religion and Economic Growth,” American Sociological Review, October.

Bell, Daniel (1973). The Coming of Post-Industrial Society: A Venture in Social Forecasting, New York, Basic Books.

Berger, P.L. (1967). The Sacred Canopy: Elements of a Sociological Theory of Religion, Garden City NJ, Doubleday.

Berman, E. (1999). "Subsidized Sacrifice: State Support of Religion in Israel," Contemporary Jewry, 20.

Chaves, M. (1994). “Secularization as Declining Religious Authority,” Social Forces, March, 749-774. 
Chaves, M. and D.E. Cann (1992). "Regulation, Pluralism, and Religious Market Structure," Rationality and Society, July, 272-290.

Chaves, M. and P.S. Gorski (2001). "Religious Pluralism and Religious Participation,” Annual Review of Sociology, 261-281.

Davie, G. (1994). Religion in Britain since 1945: Believing without Belonging, Oxford, Blackwell.

Ekelund, R.B., R.F. Hebert, and R.D. Tollison (2002). “An Economic Analysis of the Protestant Reformation," Journal of Political Economy, June, 646-671.

Finke, R. and L.R. Iannaccone (1993). "Supply-Side Explanations for Religious Change,” The Annals of the American Academy of Political and Social Sciences, May, 27-39.

Finke, R. and R. Stark (1992). The Churching of America 1776-1990, New Brunswick NJ, Rutgers University Press.

Fox, J. and S. Sandler (2003). "Separation of Religion and State in the $21^{\text {st }}$ Century: Comparing the Middle East and Western Democracies," presented at the International Studies Association conference, Portland OR, February.

Freud, S. (1927). The Future of an Illusion, New York, Norton.

Hagen, E.E. (1962). On the Theory of Social Changes: How Economic Growth Begins, Homewood IL, Dorsey.

Heston, A., R. Summers, and B. Aten (2002). Penn World Tables Version 6.1, Center for International Comparisons at the University of Pennsylvania (CICUP), October.

Hume, D. (1757). The Natural History of Religion, edited by J.C.A. Gaskin, Oxford, Oxford University Press, 1993.

Iannaccone, L.R. (1991). "The Consequences of Religious Market Structures: Adam Smith and 
the Economics of Religion," Rationality and Society, April, 156-177.

Iannaccone, L.R. and R. Stark (1994). “A Supply-Side Reinterpretation of the 'Secularization' of Europe," Journal for the Scientific Study of Religion, March, 76-88.

Inglehart, R. and W.E. Baker (2000). "Modernization, Cultural Change, and the Persistence of Traditional Values," American Sociological Review, February, 19-51.

Jeremy, D.J., ed. (1988). Business and Religion in Britain, Aldershot England, Gower.

Jeremy, D.J., ed. (1998). Religion, Business and Wealth in Modern Britain, London, Routledge.

Martin, D. (1978). A General Theory of Secularization, Oxford, Basil Blackwell.

Marx, K. (1913). A Contribution to the Critique of Political Economy, Chicago, Kerr.

McCleary, R.M. (2003). “Salvation, Damnation, and Economic Incentives," Project on Religion, Political Economy, and Society working paper no. 39, Weatherhead Center, Harvard University, November.

Sacerdote, B. and E.L. Glaeser (2001). "Education and Religion," National Bureau of Economic Research, working paper no. 8080, January.

Smith, A. (1791). An Inquiry into the Nature and Causes of the Wealth of Nations, $6^{\text {th }}$ ed., London, Strahan.

Stark, R. and W.S. Bainbridge (1987). A Theory of Religion, New York, Lang.

Troeltsch, E. (1931). The Social Teaching of the Christian Churches, v.I, London, Allen \& Unwin.

Weber, M. (1930). The Protestant Ethic and the Spirit of Capitalism, London, Allen \& Unwin.

Wesley, J. (1951). Standard Sermons, edited by E.H. Sugden, London, Epworth.

Wilson, B. (1966). Religion in Secular Society: A Sociological Comment, London, Watts.

Wooldridge, J.M. (2002). Econometric Analysis of Cross Section and Panel Data, 
Cambridge MA, MIT Press.

World Bank (2002). World Development Indicators 2002, The World Bank, Washington DC.

Worsley, I. (1816). Observations on the State and Changes in the Presbyterian Societies of England during the Last Half Century, London, Manchester Central Reference Library. 


\begin{tabular}{|c|c|c|c|c|c|c|c|}
\hline \multicolumn{8}{|c|}{ and Religious Pluralism Index for Countries in the Sample } \\
\hline Country & $\begin{array}{c}\text { State } \\
\text { religion }\end{array}$ & $\begin{array}{c}\text { State } \\
\text { regulation }\end{array}$ & $\begin{array}{c}\text { Pluralism } \\
\text { index }\end{array}$ & Country & $\begin{array}{c}\text { State } \\
\text { religion }\end{array}$ & $\begin{array}{c}\text { State } \\
\text { regulation }\end{array}$ & \begin{tabular}{|c|}
$\begin{array}{c}\text { Pluralism } \\
\text { index }\end{array}$ \\
\end{tabular} \\
\hline Argentina & 1 & 1 & 0.13 & Latvia & 0 & 1 & 0.68 \\
\hline Australia & 0 & 0 & 0.51 & Lithuania & 0 & 1 & 0.13 \\
\hline Austria & 0 & 0 & 0.15 & Luxembourg & 1 & 1 & 0.04 \\
\hline Bangladesh & 1 & 1 & 0.24 & Malaysia & 1 & 0 & 0.68 \\
\hline Belgium & 0 & 0 & 0.05 & Mexico & 0 & 0 & 0.05 \\
\hline Brazil & 0 & 0 & 0.20 & Netherlands & 0 & 0 & 0.53 \\
\hline Bulgaria & 0 & 0 & 0.28 & New Zealand & 0 & 0 & 0.37 \\
\hline Cameroon & 0 & 0 & 0.73 & Nigeria & 0 & 1 & 0.69 \\
\hline Canada & 0 & 0 & 0.56 & Norway & 1 & 1 & 0.01 \\
\hline Chile & 0 & 0 & 0.22 & Pakistan & 1 & 0 & 0.06 \\
\hline China & 0 & 1 & 0.46 & Peru & 1 & 1 & 0.09 \\
\hline Colombia & 1 & 0 & 0.05 & Philippines & 0 & 0 & 0.28 \\
\hline Cyprus & 0 & 0 & 0.36 & \begin{tabular}{|l|} 
Poland \\
\end{tabular} & 0 & 0 & 0.19 \\
\hline Czech Rep. & 0 & 1 & 0.43 & \begin{tabular}{|l} 
Portugal \\
\end{tabular} & 1 & 0 & 0.02 \\
\hline Denmark & 1 & 0 & 0.02 & Romania & 0 & 0 & 0.40 \\
\hline Dominic. Rep. & 1 & 0 & 0.05 & Russia & 0 & 1 & 0.51 \\
\hline Estonia & 0 & 1 & 0.48 & Singapore & 0 & 0 & 0.63 \\
\hline Finland & 1 & 1 & 0.03 & Slovak Rep. & 0 & 1 & 0.34 \\
\hline France & 0 & 1 & 0.17 & Slovenia & 0 & 0 & 0.12 \\
\hline Germany (W.) & 0 & 0 & 0.54 & Spain & 1 & 0 & 0.00 \\
\hline Ghana & 0 & 0 & 0.72 & Sweden & 1 & 1 & 0.08 \\
\hline Greece & 1 & 1 & 0.04 & Switzerland & 0 & 0 & 0.51 \\
\hline Hong Kong & 0 & 0 & 0.60 & South Africa & 0 & 0 & 0.63 \\
\hline Hungary & 0 & 1 & 0.47 & Taiwan & 0 & 0 & 0.58 \\
\hline Iceland & 1 & 0 & 0.03 & Thailand & 1 & 1 & 0.14 \\
\hline India & 0 & 0 & 0.31 & Turkey & 0 & 1 & 0.01 \\
\hline Ireland & 1 & 0 & 0.08 & U.K. & 1 & 1 & 0.33 \\
\hline Israel & 1 & 0 & 0.19 & Uruguay & 0 & 0 & 0.14 \\
\hline Italy & 1 & 1 & 0.01 & U.S. & 0 & 0 & 0.64 \\
\hline Japan & 0 & 0 & 0.46 & Venezuela & 1 & 1 & 0.08 \\
\hline Korea (S.) & 0 & 0 & 0.33 & & & & \\
\hline
\end{tabular}




\section{Notes to Table 1}

The presence of a state religion (value 1 for the dummy variable) refers to the situation around 1970, as designated by Barrett, Kurian, and Johnson (2001, pp. 834-35). We assigned the value one only if Barrett, et al, designated an individual religion, not if they classified the state as favoring religion in general. State regulation (value 1) refers to a situation in which the state appoints or approves church leaders. This designation comes from discussions in Barrett (1982) and Barrett, Kurian, and Johnson (2001) and elsewhere and typically applies during the late 1970s. The pluralism index is one minus the Herfindahl index based on the fractions of adherents in 1980 to nine major religions, among persons expressing adherence to some religion. The religions are Catholic, Muslim, Protestant, Hindu, Buddhist, other eastern religions, Jewish, Orthodox, and other. These data are from Barrett (1982). For the Eastern European countries shown at the end of the table, the data are from Barrett, Kurian, and Johnson (2001) and apply in 1990. The countries shown are the ones included in the subsequent statistical analysis (as dictated by data availability). 


\begin{tabular}{|c|c|c|}
\hline \multicolumn{3}{|c|}{ Table 2 Means and Standard Deviations of Variables } \\
\hline Variable & Mean & Standard deviation \\
\hline Weekly church attendance & 0.25 & 0.22 \\
\hline Monthly church attendance & 0.37 & 0.24 \\
\hline Belief in heaven & 0.56 & 0.22 \\
\hline Belief in hell & 0.38 & 0.21 \\
\hline Belief in after-life & 0.58 & 0.17 \\
\hline Belief in God in some form & 0.80 & 0.14 \\
\hline Religious person & 0.61 & 0.20 \\
\hline \multicolumn{3}{|l|}{$\log [x /(1-x)]$ for: } \\
\hline weekly attendance & -1.46 & 1.41 \\
\hline monthly attendance & -0.70 & 1.24 \\
\hline belief in heaven & 0.37 & 1.21 \\
\hline belief in hell & -0.54 & 1.07 \\
\hline belief in after-life & 0.37 & 0.77 \\
\hline belief in God & 1.77 & 1.26 \\
\hline religious person & 0.54 & 1.00 \\
\hline Log of per capita GDP & 9.33 & 0.77 \\
\hline Years of education (years) & 8.29 & 2.10 \\
\hline Urbanization rate & 0.70 & 0.16 \\
\hline Life expectancy at age 1 (years) & 73.8 & 4.8 \\
\hline 1/(life expect. at age 1) (x 100) & 1.36 & 0.11 \\
\hline Population share $>65$ & 0.111 & 0.042 \\
\hline Population share $<15$ & 0.240 & 0.077 \\
\hline Religious pluralism & 0.30 & 0.23 \\
\hline State religion & 0.32 & 0.47 \\
\hline Regulation of religion & 0.38 & 0.49 \\
\hline Communist regime & 0.23 & 0.42 \\
\hline Catholic fraction & 0.47 & 0.40 \\
\hline Eastern religion fraction & 0.075 & 0.242 \\
\hline Hindu fraction & 0.011 & 0.085 \\
\hline Jewish fraction & 0.010 & 0.073 \\
\hline Muslim fraction & 0.048 & 0.154 \\
\hline Orthodox fraction & 0.075 & 0.208 \\
\hline Protestant fraction & 0.29 & 0.33 \\
\hline Other religion fraction & 0.022 & 0.064 \\
\hline Non-religious fraction & 0.105 & 0.123 \\
\hline Average "superstition" & 0.43 & 0.14 \\
\hline
\end{tabular}




\section{Notes to Table 2}

The columns show the (unweighted) means and standard deviations of the variables used in Table 3, along with some other variables. The sample for most variables is the set of observations for which data are available for church attendance or belief in heaven and for the explanatory variables used in Table 3. For the religious belief variables, the set of observations is smaller. The religion fractions, aside from non-religious, are relative to the population of adherents to some religion. The non-religion fraction is relative to the total population. For superstition, the values refer to the average of the three indicators shown in Table 7 (available for 17 countries). 


\begin{tabular}{|c|c|c|c|}
\hline \multicolumn{4}{|c|}{ (cells show estimated coefficients with standard errors in parentheses) } \\
\hline & (1) & (2) & (3) \\
\hline explanatory variable & $\begin{array}{c}\text { weekly } \\
\text { church } \\
\text { attendance }\end{array}$ & $\begin{array}{c}\text { monthly } \\
\text { church } \\
\text { attendance }\end{array}$ & $\begin{array}{l}\text { belief in } \\
\text { heaven }\end{array}$ \\
\hline Log of per capita GDP & $-0.47(0.10) * * *$ & $-0.52(0.10) * * *$ & $-0.80(0.13)^{* * *}$ \\
\hline Religious pluralism & $2.16(0.39) * * *$ & $1.60(0.34) * * *$ & $0.78(0.48)$ \\
\hline State religion & $0.79(0.18)^{* * *}$ & $0.75(0.16)^{* * *}$ & $0.59(0.24)^{*}$ \\
\hline Regulation of religion & $-0.56(0.14)^{* * *}$ & $-0.57(0.12)^{* * *}$ & $-0.49(0.18)^{* *}$ \\
\hline Communist regime & $-0.63(0.22)^{* *}$ & $-0.72(0.21)^{* * *}$ & $-1.10(0.25)^{* * *}$ \\
\hline Ex-Communist (in 1995) & $0.09(0.22)$ & $0.13(0.22)$ & $0.26(0.32)$ \\
\hline Ex-Communist (in 1998) & $0.13(0.20)$ & $0.31(0.17)$ & $0.20(0.20)$ \\
\hline Ex-Communist (in 1999) & $0.27(0.25)$ & $0.40(0.23)$ & -- \\
\hline ISSP data & $-0.17(0.10)$ & $-0.13(0.09)$ & $0.19(0.10)^{*}$ \\
\hline Gallup data & $-0.03(0.12)$ & $-0.11(0.10)$ & -- \\
\hline Eastern religion fraction & $-2.80(0.28) * * *$ & $-2.32(0.26) * * *$ & $-0.96(0.42)^{*}$ \\
\hline Hindu fraction & $-0.73(0.56)$ & $-0.84(0.55)$ & $-3.08(0.57)^{* * *}$ \\
\hline Jewish fraction & $-1.92(0.53)^{* * *}$ & $-2.27(0.46)^{* * *}$ & $-1.30(0.45)^{* *}$ \\
\hline Muslim fraction & $1.10(0.34)^{* *}$ & $0.45(0.32)$ & $1.48(0.44)^{* *}$ \\
\hline Orthodox fraction & $-2.57(0.30) * * *$ & $-1.64(0.27)^{* * *}$ & $-1.02(0.36)^{* *}$ \\
\hline Protestant fraction & $-2.28(0.22) * * *$ & $-1.90(0.20)^{* * *}$ & $-0.71(0.26)^{* *}$ \\
\hline Other religion fraction & $1.26(0.94)$ & $1.33(0.90)$ & $3.19(1.16)^{* *}$ \\
\hline $\begin{array}{l}\text { Number of countries and } \\
\text { total observations }\end{array}$ & 61,188 & 61,185 & 51,132 \\
\hline $\begin{array}{l}\text { Number of observations for } \\
\text { each equation }\end{array}$ & $\begin{array}{l}24,38,22, \\
33,28,43 \\
\end{array}$ & $\begin{array}{l}22,37,22 \\
33,28,43\end{array}$ & $\begin{array}{l}21,34,16 \\
31,30\end{array}$ \\
\hline $\begin{array}{l}\text { R-squared for each } \\
\text { equation }\end{array}$ & $\begin{array}{l}.78, .70, .71 \\
.86, .67, .75\end{array}$ & $\begin{array}{l}.77, .63, .71 \\
.80, .75, .76\end{array}$ & $\begin{array}{c}.36, .66, .68 \\
.76, .64\end{array}$ \\
\hline
\end{tabular}




\begin{tabular}{|c|c|c|c|c|}
\hline \multicolumn{5}{|c|}{ Table 3, continued } \\
\hline & (4) & (5) & (6) & (7) \\
\hline explanatory variable & $\begin{array}{c}\text { belief in } \\
\text { hell }\end{array}$ & $\begin{array}{l}\text { belief in } \\
\text { after-life }\end{array}$ & $\begin{array}{c}\text { belief in } \\
\text { God }\end{array}$ & $\begin{array}{c}\text { religious } \\
\text { person }\end{array}$ \\
\hline Log of per capita GDP & $-0.51(0.13)^{* * *}$ & $-0.34(0.10)^{* *}$ & $-0.69(0.12)^{* * *}$ & $-0.20(0.13)$ \\
\hline Religious pluralism & $0.93(0.47)$ & $-0.16(0.38)$ & $-0.14(0.43)$ & $0.73(0.43)$ \\
\hline State religion & $0.57(0.23)^{*}$ & $0.05(0.19)$ & $0.25(0.21)$ & $0.45(0.21)^{*}$ \\
\hline Regulation of religion & $-0.42(0.17)^{*}$ & $-0.22(0.14)$ & $-0.32(0.15)^{*}$ & $-0.57(0.16)^{* * *}$ \\
\hline Communist regime & $-0.71(0.24)^{* *}$ & $-1.03(0.21)^{* * *}$ & $-1.41(0.25)^{* * *}$ & $-0.51(0.24)^{*}$ \\
\hline Ex-Communist (in 1995) & $0.72(0.30)^{*}$ & $0.27(0.26)$ & $0.06(0.35)$ & $0.54(0.24)^{*}$ \\
\hline Ex-Communist (in 1998) & $0.37(0.21)$ & $0.38(0.17)^{*}$ & $0.42(0.21)^{*}$ & $0.31(0.24)$ \\
\hline Ex-Communist (in 1999) & -- & -- & $0.85(0.30)^{* *}$ & -- \\
\hline ISSP data & $0.46(0.10)^{* * *}$ & $0.23(0.08) * *$ & $0.07(0.11)$ & $-0.64(0.12) * * *$ \\
\hline Gallup data & -- & -- & $-0.56(0.14)^{* * *}$ & -- \\
\hline Eastern religion fraction & $-0.26(0.39)$ & $-0.34(0.29)$ & $-1.59(0.32) * * *$ & $-2.21(0.32)^{* * *}$ \\
\hline Hindu fraction & $-1.23(0.65)$ & $-1.84(0.49)^{* * *}$ & $-1.35(0.68)$ & $-0.40(0.64)$ \\
\hline Jewish fraction & $-0.71(0.44)$ & $-0.81(0.37)^{*}$ & $-1.17(0.43)^{* *}$ & $-1.94(0.51) * * *$ \\
\hline Muslim fraction & $2.41(0.47)^{* * *}$ & $0.41(0.37)$ & $0.50(0.54)$ & $0.57(0.45)$ \\
\hline Orthodox fraction & $-0.61(0.36)$ & $-0.35(0.29)$ & $-0.40(0.30)$ & $-0.61(0.38)$ \\
\hline Protestant fraction & $-1.24(0.26)^{* * *}$ & $-0.28(0.21)$ & $-1.17(0.24)^{* * *}$ & $-1.10(0.23) * * *$ \\
\hline Other religion fraction & $1.86(1.17)$ & $2.13(0.96)^{*}$ & $4.00(1.14)^{* * *}$ & $2.55(1.07)^{*}$ \\
\hline $\begin{array}{l}\text { Number of countries and } \\
\text { total observations }\end{array}$ & 51,132 & 53,137 & 59,174 & 51,135 \\
\hline $\begin{array}{l}\text { Number of observations } \\
\text { for each equation }\end{array}$ & $\begin{array}{c}21,34,16 \\
31,30 \\
\end{array}$ & $\begin{array}{c}26,34,16 \\
31,30 \\
\end{array}$ & $\begin{array}{l}23,32,16 \\
31,30,42 \\
\end{array}$ & $\begin{array}{c}21,37,15 \\
32,30 \\
\end{array}$ \\
\hline $\begin{array}{l}\text { R-squared for each } \\
\text { equation }\end{array}$ & $\begin{array}{c}.48, .44, .56 \\
66, .56\end{array}$ & $\begin{array}{c}.42, .49, .61 \\
.55, .47 \\
\end{array}$ & $\begin{array}{l}.52, .54, .73 \\
.75, .70, .55 \\
\end{array}$ & $\begin{array}{c}.51, .59, .60 \\
.59, .46 \\
\end{array}$ \\
\hline
\end{tabular}

${ }^{*} \mathrm{p}$-value $<.05, * * \mathrm{p}$-value $<.01, * * * \mathrm{p}$-value $<.001$. 


\section{Notes to Table 3}

Each system has five or six equations, corresponding to observations on the dependent variables at five or six points in time: 1981-84, subsequently called 1981 (World Values Survey data mostly for 1981, supplemented by information from Gallup surveys for a few countries); 1990-93, subsequently called 1990 (WVS data mostly for 1990, plus observations on some variables for Greece in 1987 from Eurodim); 1990-93, subsequently called 1991 (International Social Survey Programme data mostly for 1991); 1995-97, subsequently called 1995 (WVS data mostly for 1995 or 1996); 1998-2000, subsequently called 1998 (ISSP data mostly for 1998); and 1999 (Gallup Millennium Survey). The last source has data only for church attendance and belief in God. The dependent variables are population averages for countries of (1) weekly church attendance, (2) monthly church attendance, (3) belief in heaven, (4) belief in hell, (5) belief in an after-life, (6) belief in god, and (7) persons who consider themselves religious. The measured value is the fraction of people attending, the fraction who hold the belief, or the fraction who consider themselves religious. For example, in system 1, weekly church attendance is observed for 24 countries with 1981 data, 38 countries with 1990 data, 22 countries with 1991 data, 33 countries with 1995 data, 28 countries with 1998 data, and 43 countries with 1999 data. The form of each dependent variable is $\log [\mathrm{x} /(1-\mathrm{x})]$, where $\mathrm{x}$ is the fraction of persons attending or believing or considering themselves religious.

The log of real per capita GDP, from Heston, Summers, and Aten (2002), is for 1980 in the 1981 equation, 1990 in the equations for 1990 and 1991, and 1995 in the equations for 1995, 1998, and 1999. Because of missing data for 1990, GDP data for 1995 are used for Bulgaria and Russia in the equations for 1990 and 1991. Because of missing data for 1995, GDP data for 1990 are used for West Germany in the systems for 1995 and 1998. The measures of religious pluralism, state religion, state regulation of religion, and religious adherence are discussed in the text. The dummy for the presence of a Communist regime applies to the pre-1990 period. The 1995 and later equations also include a dummy for whether the country had been Communist but is no longer Communist. For example, in the 1995 equations, the total effect for a former Communist country equals the coefficient on the Communist dummy plus the coefficient on the ex-Communist (in 1995) dummy. The dummy for the use of ISSP data applies to the 1991 and 1998 equations and that for Gallup applies to the 1999 equation.

Each system is estimated by the seemingly-unrelated (SUR) method, which allows the error terms to be correlated over the time periods for each country. This procedure does not weight countries differentially for size or other characteristics. Constant terms, not shown, are included for each system. The constants vary by system but not across the equations within a system. 


\begin{tabular}{|c|c|c|c|c|}
\hline \multicolumn{5}{|c|}{ and Belief in Heaven for 1990 WVS Sample } \\
\hline Country & $\begin{array}{c}\text { Monthly church } \\
\text { attendance }\end{array}$ & Fitted attendance & $\begin{array}{c}\text { Belief in } \\
\text { heaven }\end{array}$ & Fitted belief \\
\hline Argentina & 0.55 & 0.57 & 0.69 & 0.75 \\
\hline Austria & 0.44 & 0.39 & 0.47 & 0.54 \\
\hline Belgium & 0.35 & 0.38 & 0.34 & 0.54 \\
\hline Bulgaria & 0.09 & 0.17 & 0.16 & 0.36 \\
\hline Brazil & 0.50 & 0.59 & 0.76 & 0.79 \\
\hline Canada & 0.40 & 0.35 & 0.71 & 0.53 \\
\hline Chile & 0.46 & 0.62 & 0.77 & 0.82 \\
\hline China & 0.01 & 0.13 & -- & -- \\
\hline Czech Rep. & 0.11 & 0.18 & -- & -- \\
\hline Denmark & 0.11 & 0.16 & 0.19 & 0.48 \\
\hline Finland & 0.11 & 0.10 & 0.55 & 0.38 \\
\hline France & 0.17 & 0.28 & 0.32 & 0.43 \\
\hline Germany & 0.33 & 0.34 & 0.37 & 0.53 \\
\hline Greece & 0.29 & 0.16 & -- & -- \\
\hline Hungary & 0.34 & 0.20 & 0.27 & 0.31 \\
\hline Iceland & 0.09 & 0.16 & 0.57 & 0.50 \\
\hline India & 0.34 & 0.20 & 0.43 & 0.50 \\
\hline Ireland & 0.88 & 0.61 & 0.90 & 0.73 \\
\hline Italy & 0.51 & 0.42 & 0.52 & 0.56 \\
\hline Japan & 0.14 & 0.11 & 0.43 & 0.37 \\
\hline Latvia & 0.09 & 0.16 & 0.12 & 0.26 \\
\hline Mexico & 0.63 & 0.51 & 0.70 & 0.72 \\
\hline Netherlands & 0.13 & 0.09 & 0.37 & 0.54 \\
\hline Nigeria & 0.88 & 0.80 & 0.96 & 0.97 \\
\hline Norway & 0.13 & 0.09 & 0.44 & 0.37 \\
\hline Poland & 0.85 & 0.36 & 0.80 & 0.49 \\
\hline Portugal & 0.48 & 0.62 & 0.62 & 0.75 \\
\hline Romania & 0.31 & 0.21 & 0.58 & 0.41 \\
\hline Russia & 0.06 & 0.13 & 0.18 & 0.29 \\
\hline Slovak Rep. & 0.40 & 0.19 & -- & -- \\
\hline Slovenia & 0.35 & 0.28 & 0.30 & 0.35 \\
\hline South Africa & -- & -- & 0.90 & 0.90 \\
\hline Spain & 0.40 & 0.59 & 0.52 & 0.72 \\
\hline Sweden & 0.10 & 0.11 & 0.31 & 0.38 \\
\hline Switzerland & 0.43 & 0.33 & 0.45 & 0.49 \\
\hline Turkey & 0.38 & 0.50 & 0.87 & 0.89 \\
\hline U.K. & 0.26 & 0.20 & 0.62 & 0.48 \\
\hline U.S. & 0.58 & 0.36 & 0.87 & 0.57 \\
\hline
\end{tabular}

Notes: The data are from the 1990 World Values Survey (WVS) and cover only countries included in that survey. (Greece, covered by 1987 Eurodim, is also included.) The fitted values for monthly church attendance and belief in heaven come from the systems in columns 2 and 3, respectively, of Table 3. 


\begin{tabular}{|c|c|c|c|}
\hline \multicolumn{4}{|c|}{ (cells show estimated coefficients with standard errors in parentheses) } \\
\hline & (1) & (2) & (3) \\
\hline instrumental variables & $\begin{array}{c}\text { weekly church } \\
\text { attendance }\end{array}$ & $\begin{array}{l}\text { monthly church } \\
\text { attendance }\end{array}$ & $\begin{array}{c}\text { belief in } \\
\text { heaven }\end{array}$ \\
\hline $\begin{array}{l}\log \text { of per capita GDP in } \\
1970\end{array}$ & $\begin{array}{l}-0.50 * * * \\
(0.11)\end{array}$ & $\begin{array}{l}-0.53 * * * \\
(0.10)\end{array}$ & $\begin{array}{l}-0.93 * * * \\
(0.14)\end{array}$ \\
\hline $\begin{array}{l}\text { latitude and land-locked } \\
\text { status }\end{array}$ & $\begin{array}{l}-0.57 * * * \\
(0.12)\end{array}$ & $\begin{array}{l}-0.63 * * * \\
(0.11)\end{array}$ & $\begin{array}{l}-0.79 * * * \\
(0.13)\end{array}$ \\
\hline
\end{tabular}

\begin{tabular}{|l|l|l|l|l|}
\hline & $\mathbf{( 4 )}$ & $\mathbf{( 5 )}$ & $\mathbf{( 6 )}$ & $\mathbf{( 7 )}$ \\
\hline instrumental variables & $\begin{array}{c}\text { belief in } \\
\text { hell }\end{array}$ & $\begin{array}{c}\text { belief in } \\
\text { after-life }\end{array}$ & $\begin{array}{c}\text { belief in } \\
\text { God }\end{array}$ & $\begin{array}{c}\text { religious } \\
\text { person }\end{array}$ \\
\hline & & & & \\
\hline $\begin{array}{c}\text { log of per capita GDP in } \\
\mathbf{1 9 7 0}\end{array}$ & $-0.71 * * *$ & $-0.53 * * *$ & $-0.78 * * *$ & $-0.35^{*}$ \\
\hline $\begin{array}{c}\text { latitude and land-locked } \\
\text { status }\end{array}$ & $(0.14)$ & $(0.10)$ & $(0.13)$ & $(0.14)$ \\
\hline
\end{tabular}

${ }^{*}$ p-value $<.05, * * \mathrm{p}$-value $<.01, * * * \mathrm{p}$-value $<.001$

Note: The systems from Table 3 were reestimated by three-stage least squares. The instruments are the explanatory variables included in Table 3 except for the log of per capita GDP. This variable was replaced in the instrument list in the first case by the log of per capita GDP in 1970 (1995 for Eastern European countries for which earlier data were unavailable). In the second case, the instrument lists include a country's absolute value of degrees latitude and a dummy variable for whether the country is land-locked. The cells show the estimated coefficients and standard errors for the log of per capita GDP. The other explanatory variables in Table 3 are included in the regressions, but their coefficients are not shown. 


\begin{tabular}{|c|c|c|c|}
\hline \multirow{2}{*}{\multicolumn{4}{|c|}{$\begin{array}{c}\text { Table } 6 \text { Determinants of Church Attendance and Religious Beliefs: } \\
\text { Effects of Additional Economic and Demographic Variables }\end{array}$}} \\
\hline & & & \\
\hline \multicolumn{4}{|c|}{ (cells show estimated coefficients with standard errors in parentheses) } \\
\hline & (1) & (2) & (3) \\
\hline explanatory variable & $\begin{array}{c}\text { weekly church } \\
\text { attendance }\end{array}$ & $\begin{array}{c}\text { monthly church } \\
\text { attendance }\end{array}$ & $\begin{array}{l}\text { belief in } \\
\text { heaven }\end{array}$ \\
\hline Log of per capita GDP & $-0.02(0.17)$ & $0.04(0.16)$ & $-0.28(0.21)$ \\
\hline Years of education & $0.209(.040)^{* * *}$ & $0.192(.036) * * *$ & $0.253(.040)^{* * *}$ \\
\hline Urbanization rate & $-1.67(0.39)^{* * *}$ & $-1.49(0.34) * * *$ & $-1.65(0.43) * * *$ \\
\hline 1/(life expectancy at age one) & $2.1(1.3)$ & $2.2(1.2)$ & $-3.5(2.0)$ \\
\hline Population share $>65$ & $1.0(3.6)$ & $0.3(3.2)$ & $-9.8(4.8)^{*}$ \\
\hline Population share $<15$ & $4.6(2.3)^{*}$ & $5.5(2.0)^{* *}$ & $4.9(2.9)$ \\
\hline $\begin{array}{l}\text { Number of countries and } \\
\text { total observations }\end{array}$ & 59,183 & 59,181 & 50,130 \\
\hline $\begin{array}{l}\text { Number of observations for } \\
\text { each equation }\end{array}$ & $\begin{array}{l}23,37,22 \\
32,28,41\end{array}$ & $\begin{array}{l}22,36,22 \\
32,28,41\end{array}$ & $\begin{array}{l}21,33,16 \\
\quad 30,30\end{array}$ \\
\hline $\begin{array}{l}\text { R-squared for each } \\
\text { equation }\end{array}$ & $\begin{array}{l}.87, .80, .77 \\
.91, .77, .72\end{array}$ & $\begin{array}{l}.87, .77, .80 \\
.89, .84, .74\end{array}$ & $\begin{array}{l}.69, .79, .90 \\
.85, .84\end{array}$ \\
\hline
\end{tabular}

\begin{tabular}{|c|c|c|c|c|}
\hline & (4) & (5) & (6) & (7) \\
\hline Explanatory variable & $\begin{array}{c}\text { belief in } \\
\text { hell }\end{array}$ & $\begin{array}{l}\text { belief in } \\
\text { after-life }\end{array}$ & $\begin{array}{l}\text { belief in } \\
\text { God }\end{array}$ & $\begin{array}{l}\text { religious } \\
\text { person }\end{array}$ \\
\hline Log of per capita GDP & $-0.28(0.18)$ & $-0.14(0.18)$ & $-0.28(0.21)$ & $0.17(0.21)$ \\
\hline Years of education & $0.234(.038) * * *$ & $0.115(.036)^{* *}$ & $0.130(.045)^{* *}$ & $0.118(0.047)^{*}$ \\
\hline Urbanization rate & $-2.11(0.41) * * *$ & $-1.42(0.36) * * *$ & $-0.90(0.41)^{*}$ & $-0.99(0.51)$ \\
\hline 1/(life expectancy at age one) & $-2.5(1.7)$ & $-5.5(1.8)^{* *}$ & $-2.8(1.5)$ & $2.4(2.1)$ \\
\hline Population share $>65$ & $-12.5(4.2)^{* *}$ & $-6.2(4.2)$ & $-7.6(3.9)$ & $-7.5(5.0)$ \\
\hline Population share $<15$ & $1.5(2.6)$ & $4.2(2.6)$ & $5.6(2.6)^{*}$ & $-1.2(3.1)$ \\
\hline $\begin{array}{l}\text { Number of countries and } \\
\text { total observations }\end{array}$ & 50,130 & 52,135 & 57,170 & 50,133 \\
\hline $\begin{array}{l}\text { Number of observations for } \\
\text { each equation }\end{array}$ & $\begin{array}{l}21,33,16 \\
\quad 30,30\end{array}$ & $\begin{array}{l}26,33,16 \\
30,30\end{array}$ & $\begin{array}{l}22,32,16, \\
30,30,40\end{array}$ & $\begin{array}{l}21,36,15 \\
\quad 31,30\end{array}$ \\
\hline $\begin{array}{l}\text { R-squared for each } \\
\text { equation }\end{array}$ & $\begin{array}{c}.77, .75, .71 \\
86, .71\end{array}$ & $\begin{array}{c}.63, .65, .74 \\
.65, .74\end{array}$ & $\begin{array}{l}.73, .66, .82 \\
.80, .78, .72\end{array}$ & $\begin{array}{c}.52, .68, .59 \\
.79, .54\end{array}$ \\
\hline
\end{tabular}

${ }^{*}$ p-value $<.05, * *$ p-value $<.01, * * *$ p-value $<.001$.

Note: Five explanatory variables (for education, urbanization, life expectancy, and population age shares) were added to the systems shown in Table 3 . The cells show the coefficients for these variables and for the log of per capita GDP. Estimation is by the SUR technique. The other explanatory variables in Table 3 are included, but their coefficients are not shown. 


\begin{tabular}{|l|c|c|c|c|}
\hline \multicolumn{5}{|c|}{ Table 7 Superstition Variables } \\
\hline Country & & & & \\
\hline & $\begin{array}{c}\text { Average of } \\
\text { 3 beliefs }\end{array}$ & $\begin{array}{c}\text { Fortune } \\
\text { tellers }\end{array}$ & Horoscopes & $\begin{array}{c}\text { Good-luck } \\
\text { charms }\end{array}$ \\
\hline Canada & & & & \\
\hline Philippines & 0.29 & 0.36 & 0.23 & 0.28 \\
\hline Austria & 0.32 & 0.32 & 0.32 & 0.32 \\
\hline France & 0.32 & 0.26 & 0.38 & 0.33 \\
\hline West Germany & 0.35 & 0.39 & 0.41 & 0.24 \\
\hline Hungary & 0.36 & 0.32 & 0.38 & 0.38 \\
\hline Ireland & 0.39 & 0.44 & 0.40 & 0.34 \\
\hline Portugal & 0.25 & 0.30 & 0.19 & 0.25 \\
\hline Switzerland & 0.34 & 0.28 & 0.30 & 0.45 \\
\hline United Kingdom & 0.42 & 0.40 & 0.47 & 0.40 \\
\hline New Zealand & 0.32 & 0.42 & 0.30 & 0.24 \\
\hline Bulgaria & 0.38 & 0.46 & 0.35 & 0.33 \\
\hline Czech Republic & 0.67 & 0.65 & 0.65 & 0.72 \\
\hline Latvia & 0.58 & 0.71 & 0.53 & 0.50 \\
\hline Russia & 0.73 & 0.80 & 0.66 & -- \\
\hline Slovak Republic & 0.55 & 0.68 & 0.56 & 0.57 \\
\hline Slovenia & 0.42 & 0.55 & 0.49 & 0.48 \\
\hline
\end{tabular}

Note: The data on belief in fortune tellers, horoscopes, and good-luck charms come from International Social Survey Programme (ISSP) 1991 and 1998. The values shown refer to the fraction of the respondents believing in each category. The numbers are averages of the 1991 and 1998 waves if both are available. Otherwise, the value refers to the available wave. For Latvia, belief in good-luck charms is unavailable, and the average of beliefs refers to the other two variables. 


\begin{tabular}{|l|c|c|c|c|}
\hline \multicolumn{4}{|c|}{ Table 8 Correlations among Superstition Variables } \\
\hline & $\begin{array}{l}\text { Average of } \\
\text { 3 variables }\end{array}$ & $\begin{array}{c}\text { Fortune } \\
\text { Tellers }\end{array}$ & Horoscopes & $\begin{array}{c}\text { Good-luck } \\
\text { charms }\end{array}$ \\
\hline $\begin{array}{l}\text { Average of } \\
\text { 3 variables }\end{array}$ & 1.0 & 0.90 & 0.94 & 0.90 \\
\hline $\begin{array}{l}\text { Fortune } \\
\text { tellers }\end{array}$ & 0.90 & 1.0 & 0.78 & 0.66 \\
\hline Horoscopes & 0.94 & 0.78 & 1.0 & 0.82 \\
\hline $\begin{array}{l}\text { Good-luck } \\
\text { charms }\end{array}$ & 0.90 & 0.66 & 0.82 & 1.0 \\
\hline
\end{tabular}

Note: The table shows the correlations of the indicated column and row variables. The underlying data are in Table 7.

\begin{tabular}{|l|c|c|c|c|c|c|c|c|}
\hline \multicolumn{7}{|c|}{ Table 9 Correlations for Religiosity Variables (ISSP data) } \\
\hline & $\begin{array}{c}\text { Average } \\
\text { super- } \\
\text { stition }\end{array}$ & $\begin{array}{c}\text { Weekly } \\
\text { attend- } \\
\text { ance }\end{array}$ & $\begin{array}{c}\text { Monthly } \\
\text { attend- } \\
\text { ance }\end{array}$ & $\begin{array}{c}\text { Belief } \\
\text { in } \\
\text { heaven }\end{array}$ & $\begin{array}{c}\text { Belief } \\
\text { in hell }\end{array}$ & $\begin{array}{c}\text { Belief } \\
\text { in God }\end{array}$ & $\begin{array}{c}\text { Belief in } \\
\text { after-life }\end{array}$ & $\begin{array}{c}\text { Religious } \\
\text { person }\end{array}$ \\
\hline $\begin{array}{l}\text { Average } \\
\text { superstition }\end{array}$ & 1.0 & -0.57 & -0.55 & -0.63 & -0.37 & -0.47 & -0.56 & -0.45 \\
\hline $\begin{array}{l}\text { Weekly } \\
\text { attendance }\end{array}$ & -0.57 & 1.0 & 0.98 & 0.89 & 0.81 & 0.78 & 0.75 & 0.82 \\
\hline $\begin{array}{l}\text { Monthly } \\
\text { attendance }\end{array}$ & -0.55 & 0.98 & 1.0 & 0.91 & 0.87 & 0.86 & 0.79 & 0.87 \\
\hline $\begin{array}{l}\text { Belief in } \\
\text { heaven }\end{array}$ & -0.63 & 0.89 & 0.91 & 1.0 & 0.91 & 0.87 & 0.92 & 0.82 \\
\hline $\begin{array}{l}\text { Belief in } \\
\text { hell }\end{array}$ & -0.37 & 0.81 & 0.87 & 0.91 & 1.0 & 0.82 & 0.79 & 0.84 \\
\hline $\begin{array}{l}\text { Belief in } \\
\text { God }\end{array}$ & -0.47 & 0.78 & 0.86 & 0.87 & 0.82 & 1.0 & 0.81 & 0.91 \\
\hline $\begin{array}{l}\text { Belief in } \\
\text { after-life }\end{array}$ & -0.56 & 0.75 & 0.79 & 0.92 & 0.79 & 0.81 & 1.0 & 0.67 \\
\hline $\begin{array}{l}\text { Religious } \\
\text { person }\end{array}$ & -0.45 & 0.82 & 0.87 & 0.82 & 0.84 & 0.91 & 0.67 & 1.0 \\
\hline
\end{tabular}

Note: The table shows the correlations of the indicated column and row variables. The data for the average of the three superstition variables are in Table 7 . The religiosity variables, also from the ISSP waves, are for the same set of countries. 